HNF-MR-0535

Revision 0

\title{
Integration Plan for Environmental Monitoring
}

(with the exception of groundwater monitoring)

Performance Agreement SM 7.2.1

\author{
Date Published \\ March 1997
}

Prepared for the U.S. Department of Energy, Richland

Operations Office, Environmental Assurance, Permits, and Policy Division

Prepared by Fluor Daniel Hanford, Inc.

with Rust Federal Services of Hanford Inc.

Effluent and Environmental Monitoring Program

Project Hanford Management Contractor for the

U.S. Department of Energy under Contract DE-AC06-96RL13200 
LEGAL DISCLAIMER

This report was prepared as an account of work sponsored by an agency of the United States Government. Neither the United States Government nor any agency thereof, nor any of their employees, nor any of their contractors, subcontractors or their employees, makes any warranty, express or implied, or assumes any legal liability or responsibility for the accuracy, completeness, or any third party's use or the results of such use of any information, apparatus, product, or process disclosed, or represents that its use would not infringe privately owned rights. Reference herein to any specific commercial product, process, or service by trade name, trademark, manufacturer, or otherwise, does not necessarily constitute or imply its endorsement, recommendation, or favoring by the United States Government or any agency thereof or its contractors or subcontractors. The views and opinions of authors expressed herein do not necessarily state or reflect those of the United States Government or any agency thereof.

This report has been reproduced from the best available copy.

Printed in the United States of Amerios

DISCLM-2,CHP (1-91) 


\section{RELEASE AUTHORIZATION}

Document

Number:

Document

Title:
HNF-MR-0535, REV. 0

Integration Plan Required by Performance Agreement SM 7.2.1

Release Date: $\quad 3 / 28 / 97$

This document was reviewed following the procedures described in WHC-CM-3-4 and is:

\section{APPROVED FOR PUBLIC RELEASE}

WHC Information Release Administration Specialist:

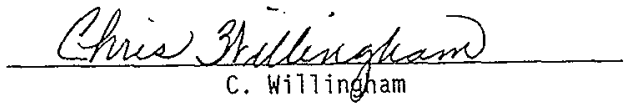




\section{Integration Plan for Environmental Monitoring}

(with the exception of groundwater)

\section{Approvals:}

Wlleim Sdai

W. D. Adair, Director

Environmental Protection

Fluor Daniel Hanford, Inc.

L: K. Trent, Vice President

Environment, Safety and Health

Fluor Dariel Hanford, Inc.
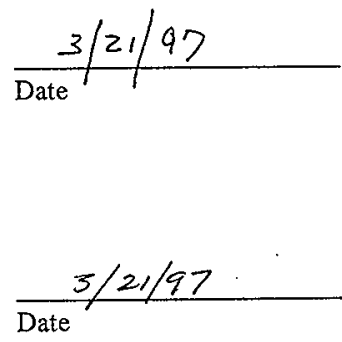

\section{Concurrence:}

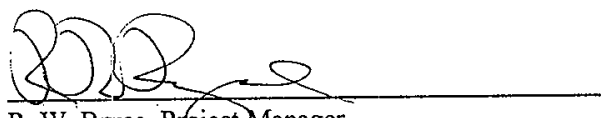

R. W. Bryce, Project Manager

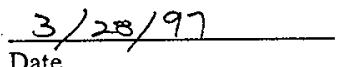

Pacific Northwest National Laboratory
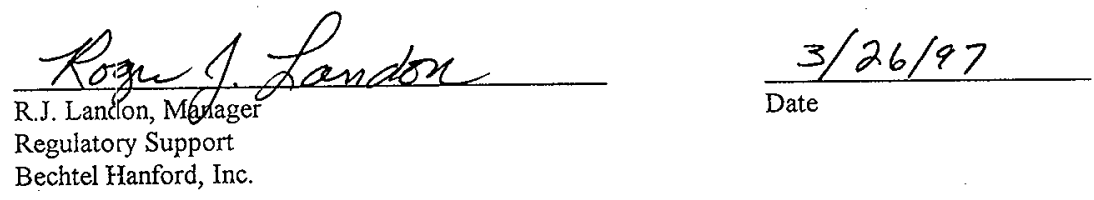
HNF-MR-0535, Rev. 0

This page intentionally left blank. 
HNF-MR-0535, Rev. 0

\section{EXECUTIVE SUMMARY}

Fluor Daniel Hanford, Inc. and its major subcontractors are in agreement that environmental monitoring performed under the Project Hanford Management Contract is to be done in accordance with a single, integrated program. The purpose of this Integration Plan for Environmental Monitoring is to document the policies, systems, and processes being put in place to meet one key objective: manage and integrate a technically competent, multi-media ambient environmental monitoring program, in an efficient, cost effective manner. Fluor Daniel Hanford, Inc. and its major subcontractors also commit to conducting business in a manner consistent with the International Standards Organization 14000 Environmental Management System concepts.

Because the integration of sitewide groundwater monitoring activities is managed by the Environmental Restoration Contractor, groundwater monitoring it is outside the scope of this document. Therefore, for the purpose of this Integration Plan for Environmental Monitoring, the Integrated Environmental Monitoring Program is defined as applicable to all environmental media except groundwater.

This document provides recommendations on future activities to better integrate the overall environmental monitoring program, with emphasis on the near-field program. In addition, included is the Fluor Daniel Hanford, Inc. team review of the environmental monitoring activities on the Hanford Site, with concurrence of Pacific Northwest National Laboratory and Bechtel Hanford, Inc. (The narrative provided later in the Discussion Section describes the review and consideration given to each topic.)

This document was developed to meet the requirements of the Project Hanford Management Contract performance agreement (SM7.2) and the tenets of the U.S. Department of Energy's Effluent and Environmental Monitoring Planning Process. This Plan is prepared for the U.S. Department of Energy, Richland Operations Office, Environmental Assurance, Permits, and Policy Division to complete the requirements specified in the Performance Expectation 7.2.1, within the SM7 Environmental, Safety, and Health section of the Project Hanford Management Contract. 
1 The verbatim performance agreement is as follows:

SM7 ENVTRONMENTAL, SAFETY, AND HEALTH. Achieve high performance in environmental stewardship at (the) Hanford Site.

7.2 Manage and integrate a technically competent, multi-media (with the exception of groundwater) ambient environmental monitoring program, in an efficient, cost effective manner.

SM 7.2.1 Submit for $R L$ approval a plan and recommendations for integration of required environmental monitoring by April 1, 1997.

The plan should contain a review of the current Hanford effluent and surface environmental monitoring activities conducted by or under the direction of FDH, PNNL, and BHI and make recommendations on how to best integrate an overall program with special emphasis on the near field monitoring program.

The plan should also be consistent with requirements contained in the current version of the proposed Rule 10 CFR 834 and DOE Orders 5400.1 and 5400.5. The plan shall address commitments to :

- A quarterly NESHAP status report.

- A Radionuclide Air Emission Report due June 30 of each year.

- FDH would coordinate with PNNL to produce the site-wide annual report (Hanford Site Environmental Report).

- Abide by 10 CFR 834 when promulgated.

- A preoperational monitoring plan for proposed facilities that generate or handle radioactive material.

The continuous efforts to integrate the environmental monitoring activities on the Hanford Site are discussed, as are past and current integration efforts. Recommendations are provided on future activities to maintain or improve the ambient environmental monitoring program. The following summarizes these recommendations.

Basic Work Requirements - No significant changes required. All activities are well defined and currently funded in the current multi-year work plans.

- Quarterly NESHAP status report--Reported quarterly per the requirements found in the NESHAP Federal Facility Compliance Agreement. 
- Radionuclide Air Emissions Report--Working with Bechtel Hanford, Inc. and Pacific Northwest National Laboratory, the Fluor Daniel Hanford, Inc. team will obtain the required certifications and transmit the report to U.S. Environmental Protection Agency, Region 10, and the Washington State Department of Health by June 30th.

- Hanford Site Environmental Report--The Fluor Daniel Hanford, Inc. team and it's subcontractors will work with Pacific Northwest National Laboratory and Bechtel Hanford, Inc. to provide the required information as indicated in the annual publication schedule.

- IO CFR 834 Implementation-A multi-contractor committee will continue to be maintained in readiness for the eventual promulgation of the rule. Implementation work has been put on hold, pending promulgation.

- Pro-operational Monitoring Plans-As new facilities or modifications to existing facilities occur, plans will be prepared and monitoring performed.

Program Reviews - The following areas were reviewed for potential methods to improve integration between contractors and among the Fluor Daniel Hanford, Inc. subcontractors. The conclusions, actions, and recommendations are described briefly with target completion date as follows. The notation Complete indicates the contractor review has been completed and the integration team will continue with its activities, pending direction from DOE-RL.

- Inform Fluor Daniel Hanford, Inc., Bechtel Hanford, Inc., and Pacific Northwest National Laboratory points of contact. The Environmental Restoration Contractor, which is Bechtel Hanford, Inc., and Pacific Northwest National Laboratory have indicated their support implementing this Integration Plan for Environmental Monitoring.

Complete

- Environmental Monitoring Plan. The 3-year cycle calls for updating during 1997, and provides an opportunity to identify areas for consistency, efficiency, and any duplication. The schedule is to begin in mid-March and be complete by the end of fiscal year 1997.

September 1997

- Integration Plan for Quality Assurance Program Plans. It is recommended that each primary contractor be responsible for maintaining a quality assurance program plan. (Note: the Project Hanford Management Contract quality assurance plans include Bechtel Hanford, Inc. emission points and these plans need to be updated.

July 1997

- Integration Plan for Laboratory Statements of Work. Project Hanford Management Contract laboratory statements of work used for environmental monitoring will be rewritten to reflect the requirements of the Quanterra statement of work.

June 1997 
- Integration of Annual Reports. A review for recommendations regarding the potential combination of the operational environmental monitoring and the environmental release reports was conducted. However, no compelling reason was identified for combining these reports at the present time.

Complete

- Integration of Effluent Procedures. A sitewide document containing the general procedures used for effluent reporting was considered. It was determined that the benefits would not justify the increased effort and expense needed to maintain and update the procedures document among three major contractors.

Complete

- Past Program Reviews. A common theme present in all past program reviews was that although progress towards integration of environmental monitoring programs was acknowledged, the need for improved communication among contractors still exists. The Fluor Daniel Hanford, Inc. team will continue to improve communication with the other major Hanford Site contractors, Bechtel Hanford, Inc. and Pacific Northwest National Laboratory through the routine meetings. Complete

Implementation of Improvements. The following recommended actions have the input and concurrence of the other major contractors.

- Teaming, Routine Meetings, and Consensus. The Fluor Daniel Hanford, Inc. team (Fluor Daniel Hanford, Inc., Rust Federal Services Hanford, Inc., and Rust Federal Services Northwest) will continue to communicate with Bechtel Hanford, Inc, Pacific Northwest National Laboratory, and the U.S. Department of Energy, Richland Operations Office in an open and timely manner. A multi-contractor team has been assigned the task of determining the purpose, schedule, and agenda for routine meetings concerning environmental monitoring issues.

- Quarterly Meeting Agenda. Change frequency to every other month and use an agenda that ensures discussion of cross-cutting issues, e.g., notices of construction and any events or activities that potentially would impact the environment.

April 1997

- Integrate Environmental Monitoring Schedules. Leaving the schedules as now published in separate documents appears to be the most practicable and cost effective approach.

Complete

- Integration Plan for Coordinating Preparation of Annual Reports. There were no serious problems identified in the production schedules.

Complete

- Sharing Monitoring Procedures, Databases. The Pacific Northwest National Laboratory methods differ only slightly from present Fluor Daniel Hanford, Inc. and Bechtel Hanford, Inc. systems. It was determined that developing a sitewide document would require additional effort and funding, with little or no gain in efficiency or consistency, and is not recommended at this time.

Complete 
- Share Radiological Control Technicians. This will be pursued only on an 'as-needed' basis.

Complete

- Exchange or Borrow Technical Personnel. Individual companies will use the specialized expertise and resources within their own companies first, and if needed, request assistance from the other Hanford Site contractors. Such support can be obrained via work orders.

Complete

- Integration Plan for Managing and Using Laboratory Services. The consolidation of all laboratory services into one contract with a single laboratory was explored. This was determined not to be effective on a sitewide basis, since no single laboratory currently has the capacity to handle all of the environmental samples nor the types of analyses required.

Complete

- Callocation of People. Collocation of staffing and equipment at the same office location wos considered but determined to be not practical. Basic objectives and operating cost expectations are different for Pacific Northwest National Laboratory, Bechtel Hanford, Inc., 'inside the fence' and 'outside the fence' (enterprise) companies.

Complete

- Cross-Training of Personnel. Future cooperative training arrangements will be used whenever possible. These opportunities will be discussed at the routine meetings to heip share the technical expertise of monitoring staffs.

Complete 
HNF-MR-0535, Rev. 0

3

4

This page intentionally left blank. 
HNF-MR-0535, Rev. 0

\section{FOREWORD}

"Protection of the environment, workers, and the public is the highest priority for members of the Fluor Daniel Hanford team. The safety and well-being of our employees, the public, and the environment must never be compromised in our aggressive pursuit of results and accomplishment of work product."

H. J. Hatch, President

Fluor Daniel Hanford, Inc.

Fluor Daniel Hanford, Inc. and its major subcontractors are in agreement that environmental monitoring performed under the Project Hanford Management Contract is to be done in accordance with a single, integrated program (with the exception of groundwater activities that are managed by Bechtel Hanford, Inc.). Employees of Fluor Daniel Hanford, Inc. are required to conduct work in accordance with this Integration Plan for Environmental Monitoring and all subcontractors performing work under the Project Hanford Management Contract are required by subcontract provisions to conduct work in accordance with this Integration Plan for Environmental Monitoring. This strategy reflects the commitment of Fluor Daniel Hanford, Inc. team to work together, to streamline processes wherever possible, and to present a unified approach to effluent and environmental monitoring).

This Integration Plan for Environmental Monitoring is sufficiently broad to define policy for all major components of the sitewide program. Detailed requirements are established and incorporated into project-specific work plans as the projects are developed.

Fluor Daniel Hanford, Inc. implements its effluent and environmental monitoring program on the basis of recognized standards and practices, as well as applicable U.S. Department of Energy and regulatory requirements. Fluor Daniel Hanford, Inc. and its major subcontractors also commit to conduct business in a manner consistent with International Standards Organization 14000 Environmental Management System concepts (ISO 1996), as the best commercial approach to address the immediate and long-term impact of its products, services, and processes on the environment on the Hanford Site. Fluor Daniel Hanford, Inc. has entered into specific Performance Agreements with the U.S. Department of Energy, Richland Operations Office to rapidly initiate the appropriate systems for International Standards Organization 14000 programs.

The federal Clean Air Act of 1990, and Amendments, with the Hanford National Emission Standards for Hazardous Air Pollutants Federal Facility Compliance Agreement (signed February 1, 1994 by the U.S. Department of Energy, Richland Operations Office and the U.S. Environmental Protection Agency) include work priorities and schedules to which U.S. Department of Energy, Richland Operations Office has committed. Much of the work required for compliance with the Clean Air Act and the National Emission Standards for Hazardous Air Pollutants Federal Facility Compliance Agreement is within the scope of the Project Hanford Management Contract, and the Fluor Daniel Hanford, Inc. team is fully committed to conduct this work in a safe, environmentally sound, timely, and cost-effective 
1 manner. The united goal is to perform work safely. This goal will be attained through the use of

2 a systematic approach that includes defining the scope of work, analyzing the situation at hand,

3 developing and implementing controls, performing the work, while critiquing that work to

4 develop improved work processes. 


\section{CONTENTS}

Summ-1

FOREWORD Foreword-1

TERMS

\subsection{INTRODUCTION AND ORGANIZATION OF THE INTEGRATION PLAN FOR}

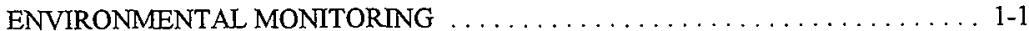

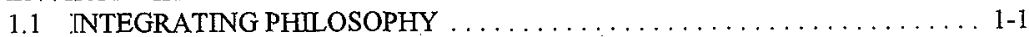

1.2 GOAL OF THE INTEGRATION TASK $\ldots \ldots \ldots \ldots \ldots \ldots \ldots \ldots \ldots \ldots$

1.2.1 Compliance with Environmental Law .................. 1-4

1.2.2 Program Plans for Environmental Monitoring . . . . . . . . . . . . 1-4

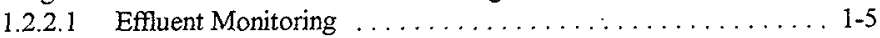

1.2.2.2 Environmental Surveillance . . . . . . . . . . . . . 1-5

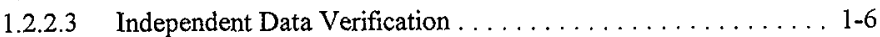

1.2.2.4 Other Sources of Effluents $\ldots \ldots \ldots \ldots \ldots \ldots \ldots \ldots \ldots$

1.2.2.5 Comprehensive Environmental Response, Compensation, and

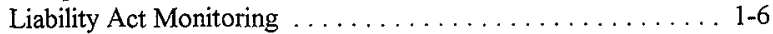

1.2.2.6 Contractor Roles ...................... 1-6

1.3 FLUOR DANIEL HANFORD, INC. LEADERSHIP ROLE . . . . . . . . 1-7

1.4 MANAGEMENT PROCESS AND STRATEGY FOR PROBLEM SOLVING, AND IDENTIFYING AND RESOLVING ISSUES $\ldots \ldots \ldots \ldots \ldots \ldots \ldots 1-7$

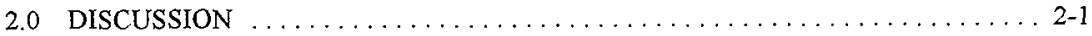

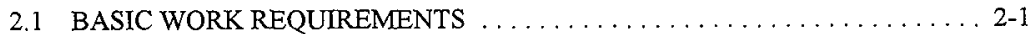

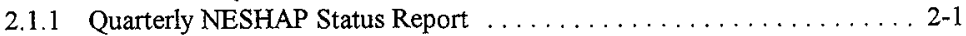

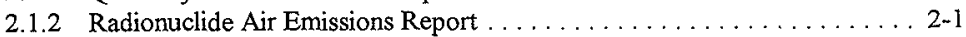

2.1.3 Hanford Site Environmental Report $\ldots \ldots \ldots \ldots \ldots \ldots \ldots \ldots \ldots . \ldots \ldots$

2.1 .4 10 CFR 834 Implementation ..........................

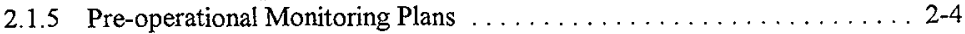

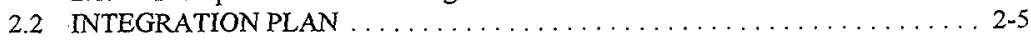

2.2 .1 Program Review . . . . . . . . . . . . . . . . . . . . .

2.2.1.1 Inform Fluor Daniel Hanford, Inc.; Bechtel Hanford, Inc.; Pacific Northwest Laboratory Points of Contact . . . . . . . 2-5

2.2.1.2 Environmental Monitoring Plan ............. 2-5

2.2.1.3 Integration Plan for. Quality Assurance Program Plans . . . . . . 2-5

2.2.1.4 Integration Plan for Laboratory Statements of Work . . . . . 2 2-6

2.2.1.5 Integration of Annual Reports . . . . . . . . . . . . . . 2-8

2.2.1.6 Integration of Effluent Procedures $\ldots \ldots \ldots \ldots \ldots \ldots \ldots .2-8$

2.2.1.7 Past Program Reviews $\ldots \ldots \ldots \ldots \ldots \ldots \ldots \ldots \ldots . . \ldots \ldots$ 


\section{CONTENTS (cont)}

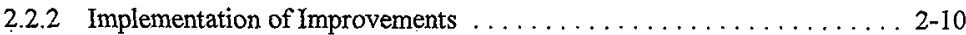

2.2.2.1 Teaming, Routine Meetings, and Consensus .......... 2-10

2.2.2.2 Quarterly Meeting Agenda $\ldots \ldots \ldots \ldots \ldots \ldots \ldots . \ldots \ldots 2-12$

2.2.2.3 Integrate Environmental Monitoring Schedules . . . . . . 2-13

2.2.2.4 Integration Plan for Coordinating Preparation of Annual

Reports ........................... 2-14

2.2.2.5 Sharing Monitoring Procedures, and Databases ........ 2-14

2.2.2.7 Exchange or Borrow Technical Personnel . . . . . . . . . . . 2-16

2.2.2.8 Integration Plan for Managing and Using Laboratory

Services ........................... 2-16

2.2.2.9 Collocation of Personnel . . . . . . . . . . . . . . . . 2-16

2.2.2.10 Cross-Training of Personnel $\ldots \ldots \ldots \ldots \ldots \ldots \ldots .2-17$

2.2.3 Basic Responsibilities of Each Major Contractor for Effluent and

Environmental Monitoring Activities ................ 2-17

2.2.4 Description of Existing Environmental Programs with Responsibilities

Related to Sitewide Integration Among Contractors and with

Regulatory Agencies . . . . . . . . . . . . . . . . . . . . . 2-18

2.2.4.1 Hanford Environmental Dose Overview Panel ......... 2-18

2.2.4.2 Quality Assurance Task Force ............... 2-18

2.2.4.3 Fluor Daniel Hanford, Inc., Environmental Integration

Group ........................... 2-18

2.2.5 Criteria Used to Establish and Measure Effluent and Environmental Monitoring Activities ....................... 2-19

2.2.5.1 Criteria Used to Ensure Consistency Without Duplication Among Contractors ...................... 2-19

2.2.5.2 Effluent and Environmental Monitoring Standards of Measurement and Reporting ................. 2-19

2.2.6 Methods for Documenting Decisionmaking, and How to Enforce the Solutions or Policies ......................... 2-20

2.2.6.1 Methods for Decisionmaking $\ldots \ldots \ldots \ldots \ldots \ldots \ldots .2-20$

2.2.6.2 Enforcing the Solutions and Policies ............ 2-22

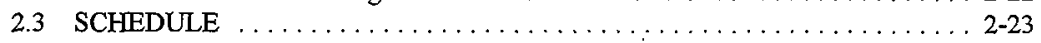

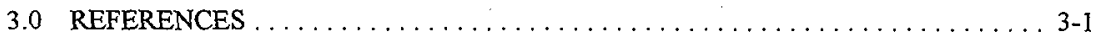


HNF-MR-0535, Rev. 0

\begin{abstract}
APPENDICES
A EFFLUENT AND ENVIRONMENTAL MONITORING

B DOE-HQ/EH-24 AUDIT SUMMARY $\ldots \ldots \ldots \ldots \ldots \ldots \ldots \ldots \ldots \ldots \ldots \ldots \ldots \ldots$

C DOE-HQ TIGER TEAM ASSESSMENT $\ldots \ldots \ldots \ldots \ldots \ldots \ldots \ldots \ldots$ C-1

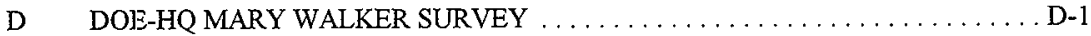

1. Monitoring and Reporting Radioactive Air Emissions $\ldots \ldots \ldots \ldots \ldots \ldots \ldots \ldots \ldots \ldots$

2. Problem/Issues Management List Development . . . . . . . . . . . . . . 1-10

3. Hanford Site Environmental Report and Radioactive Air Emissions Report Detail . . . . . . 2-2

4. Waste Sampling and Characterization Facility Laboratory

5. Environmental Release Summary Database

6. Methods for Decisionmaking. [Adapted from the Draft Management and Integration Plan (MP-001) (FDH 1997)]

1. Effluent and Environmental Monitoring Intent, Requirements, and Products . . . . . . 1-2

2. Problem Solving/Issues Management Development Process

3. Critical Problem Management List--Hypothetical Example

4. Coordination of Sitewide Air \& Water Activities Within the PHMC 


\section{TERMS}

BHI

CERCLA

CFR

CY

DESH

DOE

DOE-HQ

DOE-RL

\section{EAP}

ECO

EEM

EES

EH-24

EI

EIS/ODIS

EM

EMP

EMS

EPA

ERC

ERPP

ERS

ES\&H

FDH

FEB

FEMP

FFCA

Bechtel Hanford, Inc.

Comprehensive Environmental Response, Compensation, and Liability Act of 1980

Code of Federal Regulations

calendar year

Duke Engineering and Services Hanford, Inc.

U.S. Department of Energy

U.S. Department of Energy-Headquarters

U.S. Department of Energy, Richland Operations Office

Office of Environmental Assurance, Permits, and Policy (DOE-RL) environmental compliance officer

Effluent and Environmental Monitoring (PHMC does not include groundwater)

environmental engineering studies

Office of Environmental Audit

Environmental Integration

Effluent Information System/Onsite Discharge Information System environmental management

environmental monitoring plan

environmental management system

U.S. Environmental Protection Agency

environmental restoration contractor

environmental radiological protection program

environmental release summary

environment, safety, and health

Fluor Daniel Hanford, Inc.

facility evaluation board

facility effluent monitoring plan

Federal Facility Compliance Agreement 
HNF-MR-0535, Rev. 0

\section{TERMS (cont)}

4 FTIR

5 FY

6

7

8

9 HEDOP

10 HEPA

11 HSER

12

13 ISO

14

15 M\&I

$16 \mathrm{MDC}$

$17 \mathrm{MOU}$

18

19

33 RAE

34 RCRA

35 RCT

36 RDL
Fourier transform infrared

fiscal year

groundwater protection management plan

Hanford Environmental Dose Overview Panel

high-efficiency particulate air

Hanford Site Environmental Report

International Standards Organization

management and integration

minimum detectable concentrations

memorandum of understanding

nondestructive assays

National Emission Standards for Hazardous Air Pollutants

National Pollutant Discharge Elimination System

operational environmental monitoring program

Price Anderson Amendment Act of 1988

Project Hanford Management Contract(or)

Pacific Northwest National Laboratory

point of contact

quality assurance

quality assurance program plans

radioactive air emissions

Resource Conservation and Recovery Act of 1976

radiological control technician

required detection limits 
3

4 RFSH

5 RFSNW

6 RI/FS

7

8 SAP

9 SNF

10 SOW

11

12 WAC

$13 \mathrm{WDOH}$

14 WHC

15 WSCF

\section{TERMS (cont)}

Rust Federal Services of Hanford Inc.

Rust Federal Services Northwest

remedial investigation/feasibility study

sampling analysis plan

spent nuclear fuel

statement of work

Washington Administrative Code

Washington State Department of Health

Westinghouse Hanford Company.

Waste Sampling and Characterization Facility 
HNF-MR-0535, Rev. 0

\subsection{INTRODUCTION AND ORGANIZATION OF THE INTEGRATION PLAN FOR ENVIRONMENTAL MONITORING}

The effluent and environmental monitoring (EEM) mission is to protect the health and safety of the public, workers, and the environment by providing data concerning exposure to radioactive and hazardous constituents in environmental media. This data is essential to determining (1) if the Hanford Site is in compliance with environmental regulations and (2) if the U.S. Department of Energy, Richland Operations Office (DOE-RL) is successful in accomplishing the mission of risk reduction. Therefore, an effective, verifiable, and documented effluent and environmental monitoring program is directly linked to the success of the DOE-RL mission.

In general, this Plan leads to few specific new products. Rather, this Plan focuses on improving or enhancing existing processes and products to make these better integrated among the three major contractors: the Pacific Northwest National Laboratory (PNNL), the Environmental Restoration Contractor [Bechtel Hanford, Inc. (BHI)], and the Fluor Daniel Hanford, Inc. (FDH) team. This approach minimizes additional work scope, yet makes sitewide management of effuent and environmental monitoring, as effective and efficient as possible.

Table 1 summarizes, for each major contractor, environmental monitoring objectives, functional requirements, and products. Figure 1 displays these same elements as a flow chart.

The scope of this plan, and the specifics of its implementation, will evolve over time and through the direction of the of DOE-RL/EAP. The FDH team will work with DOE-RL to ensure that implementation of this Plan supports key decisions in a timely and effective manner. Stakeholder participation in effluent and environmental monitoring on and around the Hanford Site and, thus, in the evolution of this Plan, is essential to the long-term success of environmental monitoring. As DOE-RL continues defining the stakeholder participation process, FDH will work with the DOE-RL to ensure effective participation.

\subsection{INTEGRATING PHILOSOPHY}

Integration of a technically competent, multi-media ambient environmental monitoring program, in an efficient, cost effective manner, is an evolutionary process that must be integrated with other ongoing management processes. Implementation will begin in fiscal year (FY) 1997 and continue into FY 1998. Generally, implementation does not require any change in scope, only some adjustments in focus: In some instances (e.g., annual work prioritization), these adjustments only partially can be made in FY 1997 because execution of the management activity is already under way. In such instances, implementation will be completed in FY 1998. Any implementation requiring changes in work scope will be determined by the environmental monitoring team after discussion by all major contractors with DOE-RL at the routine meetings. A key aspect of integration is the ability of the team to make decisions by consensus at the routine or specially scheduled meetings. The environmental monitoring team will be chartered to raise issues that might impact other contractors, and seek solutions to problems with the collective wisdom of the team. 
HNF-MR-0535, Rev. 0

Table 1. Effiuent and Environmental Monitoring Intent, Requirements, and Products.

2

3

4

5

6

7

\begin{tabular}{|c|c|c|c|c|}
\hline Objective & $\begin{array}{l}\text { Functional } \\
\text { requirements }\end{array}$ & Products & $\begin{array}{l}\text { Major contractor } \\
\text { roles }\end{array}$ & $\begin{array}{c}\text { Additions/ changes to } \\
\text { processes/ } \\
\text { products }\end{array}$ \\
\hline \multirow[t]{4}{*}{$\begin{array}{l}\text { Monitoring releases to } \\
\text { the environment }\end{array}$} & \multirow[t]{2}{*}{$\begin{array}{l}\text { Identify monitoring } \\
\text { requirements }\end{array}$} & $\begin{array}{l}\text { Environmental } \\
\text { Monitoring Plan }\end{array}$ & $\begin{array}{l}\text { PNNL - lead } \\
\text { FDH Team - support } \\
\text { BHI - support }\end{array}$ & $\begin{array}{l}\text { Update this year, seek } \\
\text { efficiencies, } \\
\text { consistency, and } \\
\text { eliminate any } \\
\text { duplications }\end{array}$ \\
\hline & & $\begin{array}{l}\text { Facility Effluent } \\
\text { Monitoring Plans }\end{array}$ & $\begin{array}{l}\text { Required of all } \\
\text { contractors }\end{array}$ & $\begin{array}{l}\text { Annual reviews as } \\
\text { required }\end{array}$ \\
\hline & $\begin{array}{l}\text { Develop monitoring } \\
\text { program }\end{array}$ & $\begin{array}{l}\text { Quality Assurance } \\
\text { Program Plans }\end{array}$ & $\begin{array}{l}\text { PNNL - for their } \\
\text { emission points; } \\
\text { FDH Team - for both } \\
\text { BHI and FDH } \\
\text { emission points }\end{array}$ & Update annually \\
\hline & $\begin{array}{l}\text { Establish compliant } \\
\text { sampling intervals }\end{array}$ & Statements of Work & $\begin{array}{l}\text { PNNL - lead for } \\
\text { statement of work with } \\
\text { Quanterra; } \\
\text { FDH - lead for } \\
\text { statement of work with } \\
\text { Waste Sampling and } \\
\text { Characterization } \\
\text { Facility, } \\
325 \text { Laboratory; } \\
\text { BHI - review and } \\
\text { concur }\end{array}$ & Update annually \\
\hline \multirow[t]{2}{*}{$\begin{array}{l}\text { Annual reporting of } \\
\text { monitoring results }\end{array}$} & \multirow{2}{*}{$\begin{array}{l}\text { Demonstrate } \\
\text { compliance with } \\
\text { release limits, e.g., } \\
\text { annual offsite dose } \\
\text { limits }\end{array}$} & $\begin{array}{l}\text { Hanford Site } \\
\text { Environmental Report }\end{array}$ & $\begin{array}{l}\text { PNNL - lead; } \\
\text { FDH and BHI support }\end{array}$ & Compile data annually \\
\hline & & $\begin{array}{l}\text { Radioactive Air } \\
\text { Emissions Report to } \\
\text { EPA; } \\
\text { Effluent Information } \\
\text { System/Onsite } \\
\text { Discharge Information } \\
\text { System Report to DOE }\end{array}$ & $\begin{array}{l}\text { FDH Team - lead; } \\
\text { PNNL and } \\
\text { BHI support }\end{array}$ & $\begin{array}{l}\text { Compile data and } \\
\text { certify annually }\end{array}$ \\
\hline
\end{tabular}

12 
HNF-MR-0535, Rev. 0

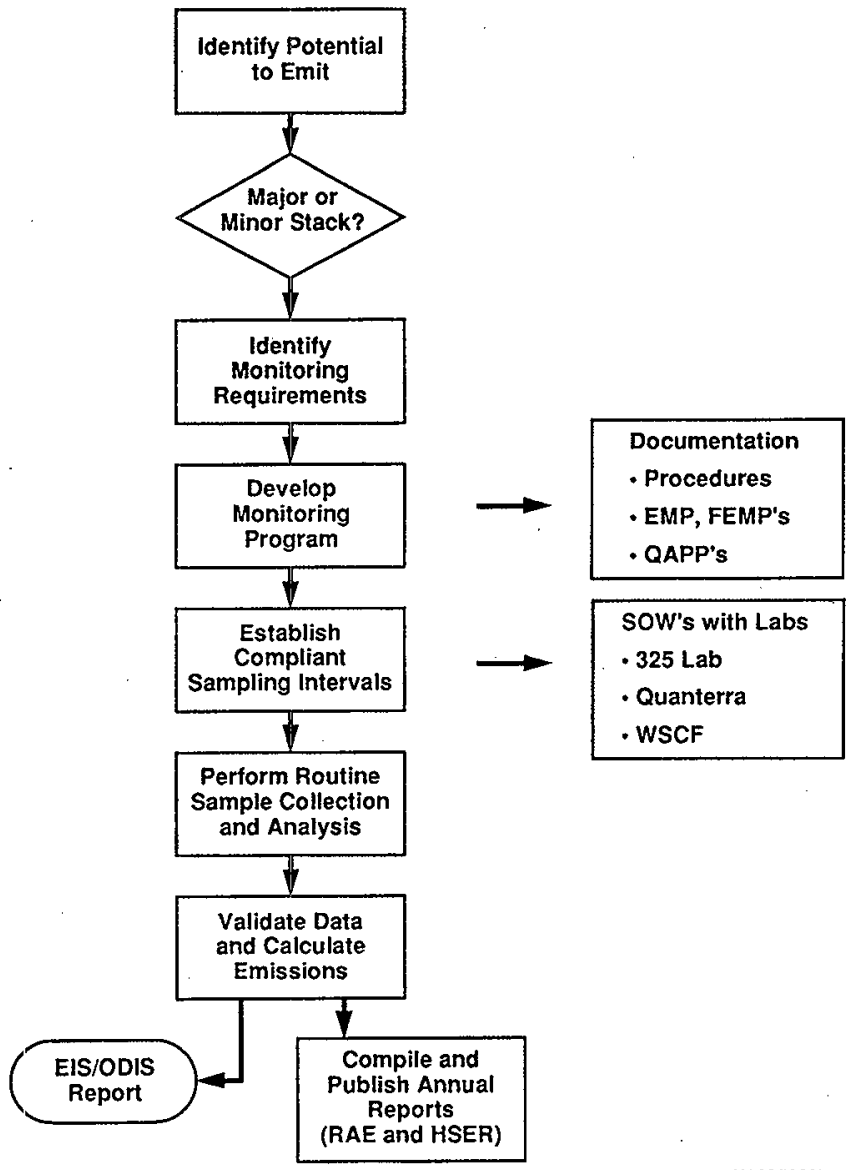

H96070007.1

Figure 1. Monitoring and Reporting Radioactive Air Emissions. 
Experience with implementation could result in changes to this Plan. If so, future revisions to this Plan will be required or the changes could be incorporated into the Environmental Monitoring Plan (EMP) during the upcoming revision (DOE/RL-91-50).

\subsection{GOAL OF THE INTEGRATION TASK}

The primary goal of the environmental monitoring programs is to protect the public and the environment by monitoring radioactive and hazardous constituents in effluents and the environment around the facilities, the site, and nearby communities. The goals of this Plan are to improve communications and seek efficiencies in all environmental monitoring activities and to be consistent with the goals of the EMP (DOE/RL-91-50).

\subsubsection{Compliance with Environmental Law}

A significant goal of the environmental monitoring program is to maintain and improve compliance with federal and state and U.S. Department of Energy (DOE) requirements. Monitoring data are collected, evaluated, and reported to determine their degree of compliance with applicable federal and state regulations and permits. Every environmental monitoring activity must have a regulatory basis, or be directed by DOE policy that is based on public health risk, public confidence, and stakeholder interests. The regulatory bases for virtually all the environmental monitoring activities described in this Plan are given as follows:

- Clean Air Act (40 CFR 61, 40 CFR 70)

- DOE Orders (5400.1, 5400.5, 5484.1, 5820.2A), (10 CFR 834, 835)

- Washington Administrative Code (WAC) (246-247, 173-400).

\subsubsection{Program Plans for Environmental Monitoring}

The technical bases, design criteria, and rationale for performing.DOE-sponsored environmental monitoring on the Hanford Site are documented in the EMP. Therefore, the goals of the EMP are summarized here for information and review.

According to DOE Order 5400.1, each DOE site, facility, or activity that uses, generates, releases, or manages significant quantities of hazardous materials will provide a written EMP covering two major activities: (1) effluent monitoring and (2) environmental surveillance. The EMP addresses those activities and consists of a summary of all the facility effluent monitoring plans, near-field environmental monitoring, surface environmental surveillance, groundwater surveillance, and meteorological monitoring. 
HNF-MR-0535, Rev. 0

Relevant to the following discussion is the definition of four terms.

- Far-field--includes both onsite and offsite (near-by communities) areas that are outside of Comprehensive Environmental Response, Compensation, and Liability Act (CERCLA) of 1980 operable units.

- CERCLA operable units--areas designated for cleanup by U.S. Environmental Protection Agency (EPA) under CERCLA.

- Near-field--area between the facility and the facilities boundary fence.

- Facility--a physical plant or project with effluents.

1.2.2.1 Effluent Monitoring. In accordance with the EMP, primary Hanford Site facilities are reviewed arunually to update the documentation of potential sources of emissions. Facility effluent monitoring plans (FEMPs) are prepared in a uniform format following the Hanford Site FEMP guidance document (WHC 1992). A FEMP is written for each facility with the potential to release significant quantities of hazardous materials, addressing both radiological and nonradiological effuent monitoring. The FEMPs contain the detailed rationale and design criteria for the effluent monitoring program, extent and frequency of monitoring and measurements, procedures for laboratory analyses, quality assurance (QA) requirements, and program implementation procedures.

Near-field environmental monitoring is an integral part of effluent monitoring activities at all facilities and certain waste disposal sites. Each facility's FEMP includes a chapter on the nearfield monitcring performed around their specific facility. The near-field program evaluates the adequacy of effluent controls or stabilization efforts near a specific facility. The program monitors radiation contamination in air, surface water, groundwater, soil, sediment, vegetation, and biota. The description of these activities contains details or specific references to the rationale and design criteria for the extent and frequency of monitoring and measurements, procedures for laboratory analysis, quality assurance (QA) requirements, and program implementation procedures.

1.2.2.2 Environmental Surveillance. PNNL sitewide environmental surveillance program assesses onsite and offsite environmental impacts and offsite human health exposures. The program monitors air, surface water, sediment, agricultural products, vegetation, soil, and wildlife. Also, PNNL conducts independent onsite surveillance to evaluate the effectiveness of Hanford Site effluent controls.

Surface environmental surveillance is described in the EMP along with the detailed rationale and design criteria for the environmental surveillance program, extent and frequency of monitoring and measurements, procedures for laboratory analysis, QA requirements, and program implementation procedures. Where possible, existing documents are referenced to minimize duplication. The EMP includes all environmental media, meteorology, and climatology monitoring. Also described is the rationale and design of the meteorology and climatology 
program, including the number and location of stations, instrumentation, forecasting capability, data management, diffusion modeling, and emergency response capability.

An annual report describing the environmental status of the Hanford Site and the surrounding area is prepared and distributed in accordance with DOE Order 5400.1 and applicable DOE-Headquarter's (DOE-HQ) guidance. This report includes environmental data collected through environmental surveillance projects and also an evaluation of Hanford Site compliance with applicable environmental standards and regulations. In addition, detailed annual reports are prepared on groundwater surveillance, operational environmental monitoring, meteorology, and climatology.

1.2.2.3 Independent Data Verification. The Washington State Department of Health (WDOH) was awarded a grant by DOE-RL in March 1990 to conduct independent surveillance, oversight, and data verification on the Hanford Site. The grant provides funds to WDOH for sample collection, analysis, data compilation and interpretation, and report preparation. The WDOH provides the results of their independent surveillance, data verification, and oversight activities annually.

1.2.2.4 Other Sources of Effluents. In addition to the DOE facilities, private and public operations involving radioactive materials are present both on and near the Hanford Site. US Ecology and Washington Public Power Supply System are the onsite operations; Siemens Nuclear Power Corporation, Battelle Memorial Institute, and the Allied Technology Group are the local offsite users of radioactive material. These operations are licensed by the U.S. Nuclear Regulatory Commission or the WDOH and are not subject to DOE environmental orders, and therefore are not included in the EMP.

\subsubsection{Comprehensive Environmental Response, Compensation, and Liability Act} Monitoring. Monitoring at CERCLA operable units is conducted as part of remedial investigation/feasibility studies (RI/FS). These studies are detailed characterization of operable units that will be used as the basis for cleanup/environmental restoration. These studies are conducted by various contractors and are under the management of BHI. RI/FS monitoring for the purpose of characterization is not included in the EMP. RI/FS reports are prepared for each operable unit and are readily available. Also, the design of the RI/FS studies and the format and content of the reports are defined by CERCLA procedures.

Facility and operational monitoring conducted for $\mathrm{BHI}$ by the FDH team is included in the appropriate sections of the EMP.

1.2.2.6 Contractor Roles. The EMP describes the environmental monitoring conducted by all Hanford Site contractors. PNNL conducts the environmental surveillance, sitewide groundwater monitoring, meteorology and climatology, and effluent monitoring of their facilities. The FDH team conducts near-field environmental monitoring around facilities, tank farms, and waste burial sites; conducts near-field groundwater monitoring; and effluent monitoring on their facilities. BHI conducts CERCLA monitoring; effluent monitoring on their facilities; and monitoring of optimization of design, conceptual model development, trending, point-of-compliance, and 
remediation performance evaluation activities. PNNL reviews its monitoring schedule annually, and changes are implemented at the beginning of the calendar year. $\mathrm{BHI}$ reviews monitoring responsibilities associated with its activities.

\subsection{FLUOR DANIEL HANFORD, INC. LEADERSHIP ROLE}

FDH, as the: Management and Integration (M\&I) contractor, is committed to pro-actively managing ir.tegrated effluent and environmental monitoring. The environmental, safety, and health (ES\&H) risks will be kept to a minimum during operations and will be reduced overall as rapidly as possible. Priority for allocation of resources is determined by DOE-RL and directed to FDH in writing. Implementation will support annual DOE-RL Office of Environment, Safety, and Health (ESH) and EAP written direction in support of the DOE-HQ EM 10-Year Plan and budget and planning guidance, or their equivalent. Programmatic risks, technical workscope, cost and schedule will be monitored closely to identify opportunities for improving project performance. Unacceptable programmatic risks (e.g., because of over reliance on unproven technology) will be avoided by using technology previously established.

The authority for implementation of this Plan is derived from the PHMC. This authority, flowing through the newly drafted management and integration plan, ensures actual implementation rather than just delivery of a plan.

Further, FDH and its major subcontractors have committed, through contract Performance Agreements, to conduct business in a manner consistent with International Standards Organization (ISO) 14000 concepts. FDH will lead an effort for the FDH Team to implement an ISO 14000-consistent environmental management system (EMS). The EMS implementation plan will identify the actions necessary for the FDH team to meet the ISO 14000 Standard as written. There are no plans to become ISO 14000 registered (certified). The EMS will encompass all facilities and activities managed by the FDH team. This EMS implementation plan will implement and self-assess its activities during FY 1998.

\subsection{MANAGEMENT PROCESS AND STRATEGY FOR PROBLEM SOLVING, AND DENTIFYING AND RESOLVING ISSUES}

The purpose, scope, and content of the management process and strategy for problem solving and issue resolution are as follows.

- Purpose: To provide a tool for FDH management and DOE-RL, with input from environmental monitoring projects, to pro-actively and continuously manage and resolve problems identified in implementing and maintaining an integrated ambient environmental monitoring program.

- Sccpe: Identified in Table 2 are steps to be taken by senior management to identify and resolve problems or issues that might arise. The problems, or issues, defined as 'critical' 
are those that have the highest likelihood of occurring and the greatest negative impacts to the sitewide integrated environmental monitoring program (defined in terms of problem likelihood and consequences); or that meet one or more of the following criteria:

- immediate action is required

- management of, or solution to, the problem is a very high stakeholder priority

- a contract performance agreement is at risk

- management of the problem requires extensive and potentially difficult coordination across several PHMC organizations and/or Hanford major contractors

Critical problems generally will include any potential for environmental impact, followed by regulatory penalty or notice of violation, which are defined as high-consequence problems.

- Content: The content of the Problem Solving/Issues Management List is information identified in Table 2, and developed through the following process illustrated in Figure 2. The list can be formatted to meet the needs of individual projects and individual problems that might arise. Table 3 illustrates an example for one hypothetical environmental monitoring problem. 
Table 2. Problem Solving/Issues Management Development Process.

\begin{tabular}{|c|l|l|}
\hline Step & \multicolumn{1}{|c|}{ Element } & \multicolumn{1}{|c|}{ Description } \\
\hline 1 & Identify problem events & $\begin{array}{l}\text { From any number of sources, identify what events pose a } \\
\text { problem and generate a list of problem events. }\end{array}$ \\
\hline 2 & Determine responsibility & $\begin{array}{l}\text { Identify by name the DOE-RL POC, the responsible FDH } \\
\text { manager, the responsible contact. }\end{array}$ \\
\hline 3 & $\begin{array}{l}\text { Determine problem } \\
\text { likelihood }\end{array}$ & $\begin{array}{l}\text { Assign a rating of low, medium, or high, based on the } \\
\text { probability of the problem event occurring. (Quantitative } \\
\text { definitions are provided in WHC 1996a.)* }\end{array}$ \\
\hline 4 & Determine consequences & $\begin{array}{l}\text { Prepare a list of consequences including any or all types of } \\
\text { problems, if the problem event should occur. }\end{array}$ \\
\hline 6 & $\begin{array}{l}\text { Identify affected } \\
\text { projects/functions }\end{array}$ & $\begin{array}{l}\text { Prepare a list of Hanford Site projects/functions that are } \\
\text { affected by the problem event and its consequences. }\end{array}$ \\
\hline 7 & $\begin{array}{l}\text { Deverity } \\
\text { critical }\end{array}$ & $\begin{array}{l}\text { Assign a rating of low, medium, or high, based on how } \\
\text { negative the effect will be if a problem event occurs. } \\
\text { (Quantitative definitions are provided in WHC 1996a.) }\end{array}$ \\
\hline 9 & Uproblem is & $\begin{array}{l}\text { Using the problem value matrix (WHC 1996a), find the } \\
\text { qualitative rating located at the intersection between } \\
\text { problem likelihood and consequence severity. Designate } \\
\text { the problem as Not Critical if the problem value is less than } \\
\text { Very High and none of the criteria applies. Designate the } \\
\text { problem as Critical if the problem value is Very High, or if } \\
\text { one or more of the criteria apply. }\end{array}$ \\
\hline 8 & Develop problem actions & $\begin{array}{l}\text { Prepare a list of actions and responsibilities that will be } \\
\text { taken to avoid, transfer, share, or control the problem. } \\
\text { Identify the current status of each action as Pending, } \\
\text { Ongoing, or Complete. Prepare an action plan to ensure } \\
\text { the completion of each action. }\end{array}$ \\
\hline $\begin{array}{l}\text { Periodically review the status of the problem and action } \\
\text { plans and update all sources of information accordingly. }\end{array}$ \\
\hline
\end{tabular}




\section{Problem Assessment}

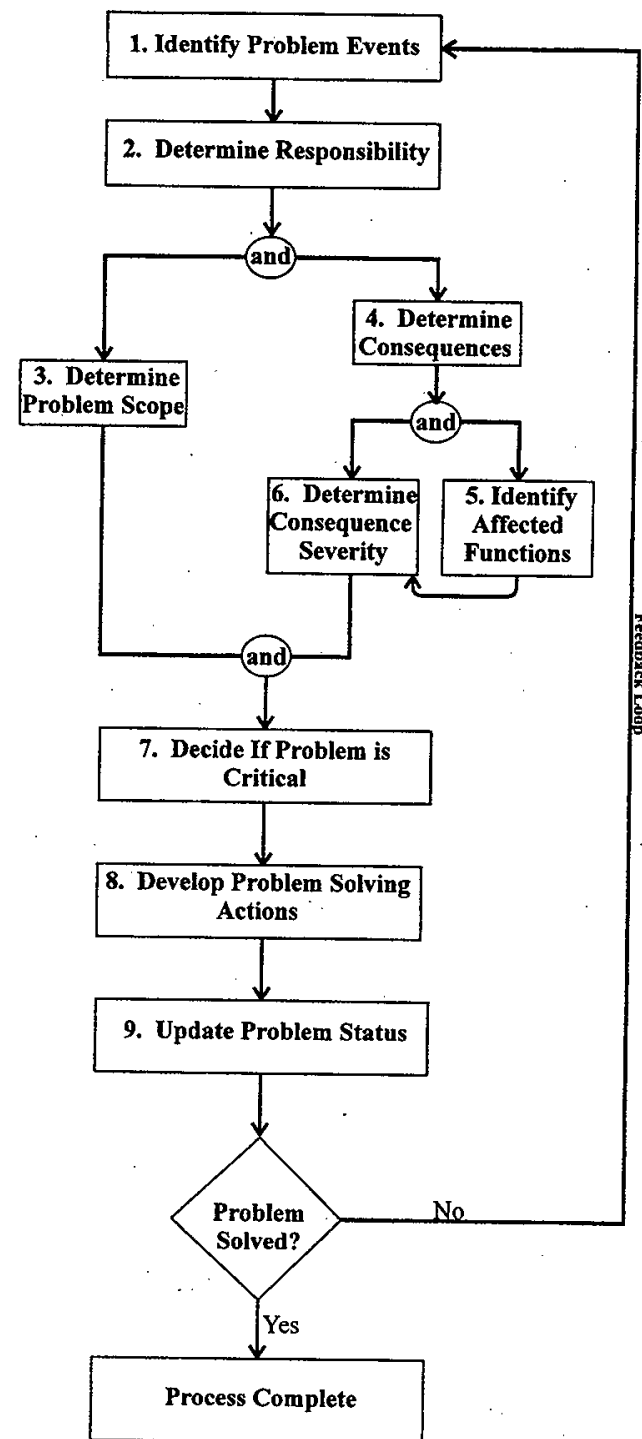

\section{Problem Handling}

Figure 2. Problem/Issues Management List Development. (The numbered elements correspond to the 'steps' in Table 2. 
Table 3. Critical Problem Management List--Hypothetical Example.

2

$\frac{4}{5}$

6

Identification number
and description

\begin{tabular}{|c|c|c|}
\hline $\begin{array}{c}\text { Critical } \\
2\end{array}$ & $\begin{array}{c}\text { Problem } \\
\text { value }\end{array}$ & Consequence(s) \\
(yes/no) & & \\
\hline
\end{tabular}

Action(s)

\begin{tabular}{|c|c|c|}
\hline Status & $\begin{array}{c}\text { Responsible } \\
\text { person }\end{array}$ & $\begin{array}{c}\text { Review } \\
\text { date }\end{array}$ \\
\hline
\end{tabular}

EEM-104 NEAR-FIELD MONITORING IS NOT SUPPORTED OR BEING DONE AS REQUIRED BY DIRECTIVES.

\begin{tabular}{|c|c|c|c|c|c|c|c|}
\hline \multirow{2}{*}{$\begin{array}{l}\text { On May } 31 \text {, a rapid } \\
\text { increase in air } \\
\text { concentrations } \\
\text { alarmed a contituous } \\
\text { air monitor in work } \\
\text { area; not monitcred } \\
\text { as an effluent. No } \\
\text { ambient air sampler } \\
\text { nearby for } \\
\text { confirmation. }\end{array}$} & \multirow[t]{2}{*}{ Yes } & \multirow[t]{2}{*}{$\mathrm{VH}$} & \multirow[t]{2}{*}{$\begin{array}{l}\text { Reduced ability to } \\
\text { safely manage and } \\
\text { report radioactive } \\
\text { releases. }\end{array}$} & $\begin{array}{l}\text { Evaluate need for } \\
\text { termination of facility } \\
\text { operations. }\end{array}$ & $\begin{array}{l}\text { See } \\
\text { attached } \\
\text { evaluation } \\
\text { in letter } \\
\text { report } x x x .\end{array}$ & $\begin{array}{l}\text { J.J. Jones } \\
\text { (FDH) }\end{array}$ & $6 / 31 / 97$ \\
\hline & & & & $\begin{array}{l}\text { Evaluate need for } \\
\text { additional } \\
\text { monitoring. }\end{array}$ & & $\begin{array}{l}\text { D.B. Cooper } \\
\text { (DES) }\end{array}$ & $6 / 31 / 97$ \\
\hline
\end{tabular}


HNF-MR-0535, Rev. 0

This page intentionally left blank. 


\subsection{DISCUSSION}

2

The following narrative summarizes each of the basic commitments listed in the Performance Agreement.

\subsection{BASIC WORK REQUIREMENTS}

The following activities presently are required by DOE Orders and federal regulations. These activities are being performed by the Effluent and Environmental Monitoring Program, as described in the Environmental Support FY 1997 Multi-Year Work Plan, WBS 1.5.2 (WHC 1996b). The following is a summary of how each activity is accomplished.

\subsubsection{Quarterly NESHAP Status Report}

A quarterly status report is required by the NESHAP FFCA. All activities during a quarter associated with the compliance plan in the FFCA are reported along with planned activities during the next quarter. The agreement between DOE-RL and the Washington State Department of Health (WDOH) and the EPA for satisfaction of the milestone is to send a fax of the report to WDOH before the Friday of the first full week of the month following the month after the quarter ends.

\subsubsection{Rarlionuclide Air Emissions Report}

Effluent sarnples are collected at specified frequencies and sent to a laboratory for analysis. Sample results are sent to the appropriate effluent monitoring POC who performs the final data verification and validation. The effluent monitoring POC enters the results into the Environmental Release Summary (ERS) database. The ERS UPDATE program calculates the releases from each major operating area. The releases are provided to PNNL, who performs the atmospheric dispersion and dose modeling using CAP88-PC (EPA 1990). All data are incorporated into a draft report, reviewed, and comments resolved. Certification is obtained by all necessary contractors and by DOE-RL. Once certified, the report is transmitted by June 30 th to the EPA and WDOH. Figure 3 provides the process flowchart for compiling this annual report. 
HNF-MR-0535, Rev. 0

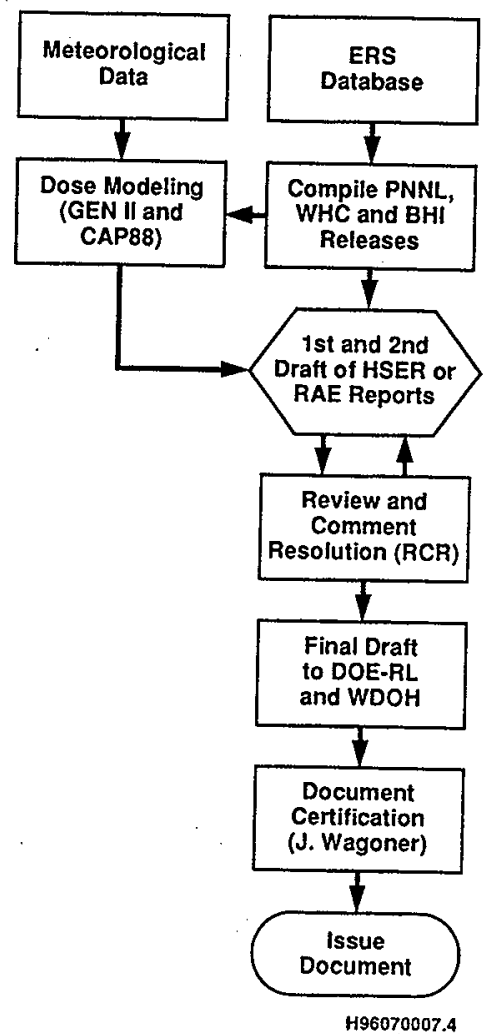

Figure 3. Hanford Site Environmental Report and Radioactive Air Emissions Report Detail. 


\subsubsection{Hanford Site Environmental Report}

FDH is committed to coordinating with the responsible PNNL program to produce the Hanford Site Envirorumental Report. The FDH team will work with PNNL and BHI to provide the following information as indicated in the annual publication schedule:

- Provide a draft of the Environmental Compliance Summary section

- Provide a draft of Effluent Monitoring, Near-Field Monitoring, Waste Management, and Chemical Inventory sections

- Review and comment will be provided on all other sections

- Prcvide peer review comments

- Comment resolution will be provided as required.

FDH will provide DOE-RL, before issuance of the Hanford Site Environmental Report (HSER), a letter of certification for that data provided by the FDH team.

\subsubsection{CFR 834 Implementation}

Title 10 of the Code of Federal Regulations (CFR), Part 834, Radiation Protection of the Public and the Environment, codifies DOE Order 5400.5 and promulgates new regulatory requirements. This rule applies to activities conducted by, or for, the DOE that could result in the release of radioactive material to the environment, exposure of members of the public to ionizing radiation, or contamination of the environment with radionuclides from DOE activities (i.e., this regulation has sitewide impacts). The new regulatory requirements under this rule will be subject to the provisions of the Price-Anderson Amendments Act (PAAA) of 1988.

To fully demonstrate compliance, 10 CFR 834.5 requires the development of an Environmental Radiological Protection Program (ERPP) plan to be submitted to and approved by DOE. The ERPP plan is required by statute to be submitted to DOE for approval 12 months following the effective date of the Rule, and once the ERPP plan is approved by DOE, the plan becomes the legally enforceable basis for compliance with 10 CFR 834 . The ERPP described in the plan consists of an ongoing series of coordinated activities that are conducted to meet the goal of protecting the public and environment from radiation exposure, consistent with the requirements of 10 CFR 834.

In response to this pending new regulation, the FDH team is conducting a project to assess current programs, document the results in a uniform format, and provide an auditable record of the basis for compliance with $10 \mathrm{CFR} 834$. As part of this effort, a tool for performing self-appraisals was designed to determine the applicability of specific sections (portions) of the rule to each facility, program, or project. The self-appraisal collects information on facilities, 
programs, and projects through a set of screening questions relating to the requirements of

10 CFR 834. The results of this initial compliance screening will directly influence the

development of the ERPP and the compliance-driven activities that must follow.

\subsubsection{Pre-operational Monitoring Plans}

7

An environmental study will be conducted to assess environmental parameters before startup of a site, facility, or process that has the potential for significant adverse environmental impact. This study should address all environmental parameters (e.g.) meteorology, hydrology, physical geology, and biology), and begin not less than 1 year (preferably 2 years) before startup to evaluate seasonal changes. This study precedes the conceptual design report and can include data acquired in the site selection process, excavation permit process, and National Environmental Policy Act of 1969/State Environmental Policy Act of 1971 process. (Basis: DOE Order 5400.1, Chapter IV, Page IV-2, Paragraph 3).

Pre-operational environmental monitoring reports were issued in 1995 and 1996 for the 200 Areas Cross-Site Transfer System; 200 Area Effluent Treatment Facility, State Approved Land Disposal Site, and the Liquid Effluent Retention Facility; and the Solid Waste Operations facilities, including the Central Waste Complex and Waste Receiving and Processing 1.

The FDH team will commit to developing pre-operational monitoring plans consistent with the following purposes:

- Determine and measure the potential impact on the new facility or process from existing contaminated sources (e.g., old waste sites) to ensure that the new facility is not affected by past practices

- Demonstrate compliance that allows determination of a cost effective level of operational monitoring that will in turn be compliant with regulations following startup of the new facility or process

- Determine pre-existing environmental conditions within the operating environment

- Quantify potential contaminant contribution of nearby waste sites to the operational environment

- Locate source terms with potential to impact the facility or operation

- Provide data to reduce costs for future monitoring during operations

- Determine levels of biotic intrusion and potential contaminant transfer pathways

- Determine differential between existing impacts and potential future impacts 
- Provide data to determine necessary action for reduction of exposure

\subsubsection{Program Review}

Activities were reviewed by the FDH team in an attempt to find potential improvements in the existing program plans and environmental reports. The reviews were accomplished with the focus on seeking enhancements, corrections, or updates to existing activities. New ideas were solicited for efficiencies, cost savings, consistencies, and to identify any unnecessary duplication of effort.

\subsubsection{Inform Fluor Daniel Hanford, Inc.; Bechtel Hanford, Inc.; Pacific Northwest} Laboratory Points of Contact. Messages and meetings have been used to share the purpose of this effort with the major contractors and seek their input and involvement. Both BHI and PNNL POCs have provided their support during this effort, including their invaluable review and input to this plar.

2.2.1.2 Elnvironmental Monitoring Plan. The upcoming 1997 review and update of the EMP (DOE/RL 91-50) will be used by all contractors as an opportunity to identify areas for consistency, efficiency, duplication, etc., as a normal course of plan preparation. The current schedule for updating the EMP starts in mid-March with the EMP completed by the end of FY 1997. The DOE/RL approval and publication must occur before the November 7, 1997 deadline.

2.2.1.3 Integration Plan for Quality Assurance Program Plans. The QAPP documents and describes how a program meets its QA objectives. The existing programs for each of the primary contractors on the Hanford Site differ slightly, because there is often more than one way to meet the same objective. It would be difficult to issue and update an integrated QAPP for all Hanford Site contractors. Items such as integrating different terminologies, schedules, inter-contractor 
relationships, and organizational structures would be time consuming and not cost effective. It is recommended that each primary contractor be responsible for maintaining a QAPP for their portions of the EEM Program. The QAPP prepared by the FDH team includes effluents under BHI management.

2.2.1.4 Integration Plan for Laboratory Statements of Work. The following SOWs were compared for consistency, Statement of Work for Analytical Services Provided to Westinghouse Hanford Company by the Pacific Northwest National Laboratory Analytical Chemistry Laboratory, (WHC 1996c); Contract 163589 - Sixth Operational Year Statement of Work Effective July 15, 1996 (PNNL 1996); and the Statement of Work for Analytical Services

11 Provided by the Waste Sampling And Characterization Facility for the Effluent and Environmental Monitoring Program During Calendar Year 1997 (HNF 1997). Figure 4 provides a flow diagram of the collection and analysis process.

The following minor differences were identified.

- Turnaround times were not consistent. This varied by as much as 35 to 70 days for individual analyses. Also, it was not clear if the units used in the SOWs were in business days (WHC 1996c and HNF 1997). This needs to be clarified.

- Laboratories were asked to meet required detection limits (RDL) or minimum detectable concentrations (MDC). These levels were not consistent. The MDC levels were sometimes 2 to 3 orders of magnitude higher than those listed in the Contract 163589 SOW (PNNL 1996).

- Cost for analysis varied for each type of analysis. The methods of indicating cost should be standardized. Gross alpha and beta might be considered one analysis for costing purposes at one laboratory and not at another laboratory.

- The limits set for precision and accuracy need to be standardized for each SOW. The Contract SOW limits for precision were $<20 \%$ and was vague as to quantifying the accuracy values (WHC 1996c). The Contract 163589 SOW was detailed in comparison (PNNL 1996).

The sample flowrate for air samples should be 2 cubic feet per minute for the period of collection unless otherwise indicated. Because the volume of the sample is the basis for determining MDC or RDL, a minimum volume of air sample should be provided, and the units should be consistent $[20,000$ cubic feet in HNF 1997 and 800 cubic meters in the Contract 163589 SOW (PNNL 1996)]. 


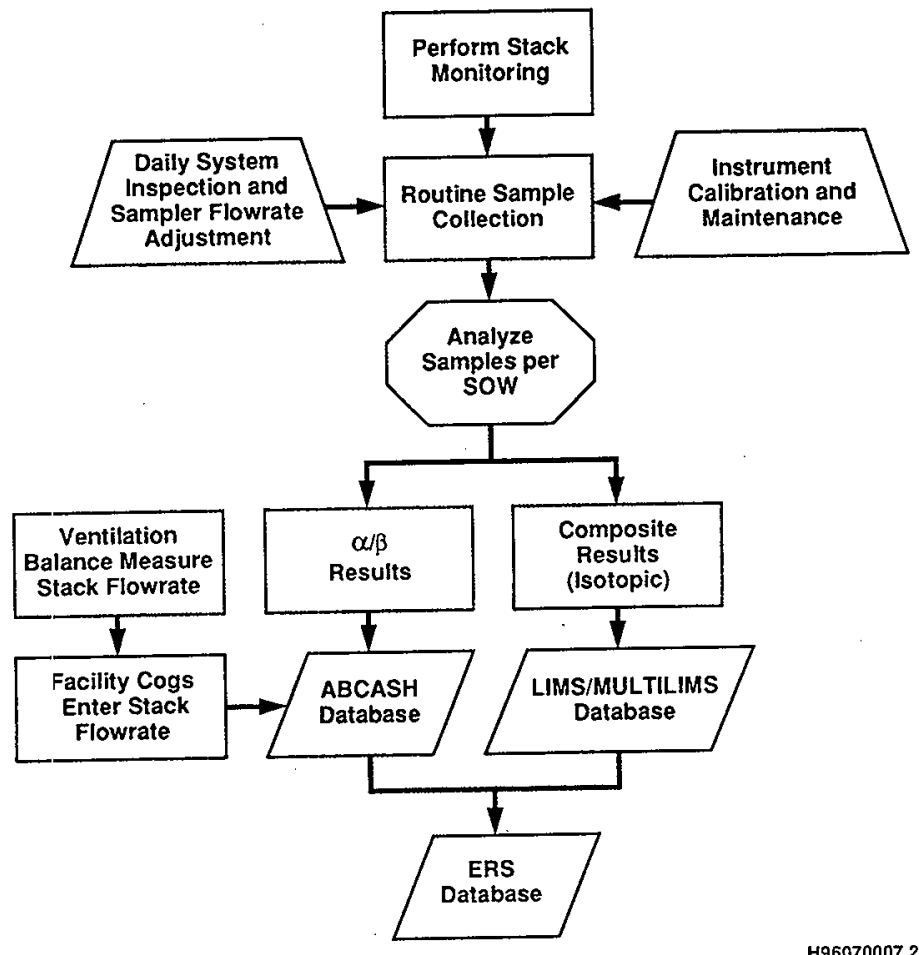

H96070007.2

Figure 4. Waste Sampling and Characterization Facility Laboratory. 
2.2.1.5 Integration of Annual Reports. The following reports were reviewed:

- Hanford Site Environmental Report (a summary of multiple reports)

- Operational Environmental Monitoring Report (detail of near-field monitoring, both for the PHMC and $\mathrm{BHI}$ )

- Environmental Release Report (detail of all environmental releases)

- Radioactive Air Emissions Report (regulatory format directed by DOE-HQ).

The possibility of combining the four annual reports was reviewed, and only two reports offered any perceived advantage from consolidation. These are the Operational Environmental Monitoring and the Environmental Releases reports.

The advantages of combining these two reports are that both reports go to the same audience and the data complement each other. The disadvantages of combining these two reports is that the reports are prepared for different purposes and by different programs and contractors. There are no compelling reasons or measurable cost savings identified for combining these reports.

Therefore, no changes are recommended at the present time.

The reduction of size and/or balance of detail within sections of the four reports was reviewed. Only the operational environmental monitoring report was identified as having an off-balance of detail within sections. Section 3 of the subject report will be reduced in detail, and the groundwater data will be published by BHI and PNNL in a separate report.

The use of the Internet (common homepage) was investigated. At the present time, the HSER is available on the Internet. The cost of making the reports available for issuance on the Internet is $\sim \$ 8,000$ per report according to $\mathrm{PNNL}$, but most persons prefer to have access to hard copy reports. Making the reports available on a common homepage (DOE-RL) would be useful, but might be limited by cost.

2.2.1.6 Integration of Effluent Procedures. The FDH and $B H I$ effluent reporting procedures are documented (WHC 1996a). The BHI contracts Rust Federal Services Hanford (RFSH) Air \& Water Services to calculate and analyze the raw data, and report their airborne releases. PNNL documents their effluent reporting procedures annually with their airborne release calculations. As a result, there does not appear to be any duplication of effort, because PNNL's method of documentation is significantly different than for FDH.

The methods used in processing sample data, calculating routine releases, and reporting that information are developed and documented differently by the primary contractors. The general methods for performing this work should be consistent throughout the Hanford Site, with the only differences being attributed to differences in equipment used. 
Further integration of effluent procedures would help ensure consistent methodologies are used. A sitewide document containing the general procedures used for effluent reporting only appears to help with this integration. The creation of a sitewide effluent procedures document would not reduce the level of effort associated with documenting the methods used for calculating radioactive effluents. The creation of a sitewide procedures document would increase the level of effort and the costs associated with documenting these methods. There are only subtle differences in calculational methods, and the accuracy of data reported to two significant figures is not affected. As a result, the integration of these procedures is not recommended at this time.

2.2.1.7 Past Program Reviews. Since 1986, there have been three major audits of Hanford Site environmental programs, numerous smaller audits and surveys, and several program self-assessments. These audits have had a significant impact on the evolution of the environmental programs on the Hanford Site, and it is important to have a basic understanding of those impacts. Perhaps the greatest accomplishment of these surveys and audits, aside from identifying individual items that needed correcting, has been to instill a mind-set of continually. looking for problems and ways to do things better. The outgrowth of these audits has been rigorous self-assessments that generally have anticipated and corrected potential problems. As a result, the Hanford Site surface environmental monitoring program has received praise in recent surveys and audits. Examples are the most recent audit, Office of Environmental Audit (EH-24), and the Westinghouse President's Office audit. A direct result of these audits is that environmertal monitoring contractors meet quarterly to share technical developments, changes in regulations, lessons learned, collocation of environmental sampling, and eliminating duplication of effort.

The most recent self-assessment of the Near-Field Monitoring Program, conducted in 1995, identified the successful closure of integration items found in earlier audits, but more importantiy identified changing environmental parameters that need close scrutiny to ensure compliance. The self-assessment was conducted of the Westinghouse Hanford Company's (WHC) Effluent Monitoring and Operational Environmental Monitoring Programs. The assessment was conducted to measure progress towards gaining compliance with findings and suggestions from past audits and surveys such as the US DOE-HQ Environmental Survey of 1986 (also known as the 'Mary 'Nalker Survey'), the Tiger Team Audit, and the DOE-HQ EH-24 Environmental Audit. The impaci to the existing envircnmental monitoring program was not significant. Progress towards integration of environmental monitoring programs by other contractors was noted, through improvement in implementation and communication among contractors was seen as necessary. A summary of the specific notations of the self-assessment are included in Appendix A.

In May of 1994, the Office of Environmental Audit (EH-24) conducted a routine environmental audit of the Hanford Site. There were no findings directed towards the Operational Environmental Monitoring Program (OEMP) under the direction of Environmental Engineering Studies (EES). In fact, there was praise given to EES for their point-by-point justification of rationale for surface water sampling points as part of self-assessment response actions and thorough self-assessment of the OEMP against the DOE Regulatory Guide DOE/EH-0173T. Also noted was that the Hanford Site maintained an exceptionally high quality of formal 
1 documentation, both in procedures and QA. While the EH-24 audit was relatively complimentary

2 of the surface environmental monitoring program, there were 11 areas, primarily in groundwater

3 monitoring, where it was noted that integration could improve. The findings of the audit are

4 summarized in Appendix B.

5

In June 1989, the Secretary of Energy announced a 10-point initiative to conduct independent oversight compliance and management assessments of the Environmental, Safety and Health $(E S \& H)$ programs at the DOE facilities. To implement that plan, a Tiger Team consisting of individuals who were knowledgeable in ES\&H activities was assembled and conducted reviews of DOE sites. In anticipation of this event, the DOE-RL Manager initiated a Hanford Self-Assessment in November 1989 to identify current ES\&H conditions before the Tiger Team visit. The Hanford Self-Assessment was issued April 20,1990 (9001817B) and identified three major causes for existing problems: aging facilities, major changes resulting from the consolidation from eight contractors to four, and a history of inadequate discipline in planning, analysis and corrective action. The Tiger Team Assessment was conducted from May 21, 1990 to July 18, 1990, and a draft report was issued (DOE/EH-0139). Findings of the Tiger Team Audit are summarized in Appendix C.

The first major inspection, although called a 'survey' rather than an audit, was the DOE-HQ Environmental Survey of 1986 (the so-called 'Mary Walker Survey'), which considered all aspects of environmental monitoring at DOE Sites. On the Hanford Site this survey resulted in 58 'findings' that were tracked until closure or incorporation into a subsequent audit. Of these 58 findings, five were directed to problems in groundwater monitoring, seven to surface environmental monitoring, and three to integration issues of environmental monitoring. All findings are now closed or incorporated into a more recent audit. The action plan identifying status of closure of the 58 findings is summarized in Appendix D.

\subsubsection{Implementation of Improvements}

The following activities were reviewed and discussed with peers for consideration and possible implementation. The implementation of any of these activities would require the approval and support of all the major contractors, as well as the DOE-RL.

\subsubsection{Teaming, Routine Meetings, and Consensus. The integration of the PHMC} contractors has become a new challenge. There are efforts to provide a network of effective communications among the many contractors. Clear lines of responsibility are being established for environmental activities. For example, the letter dated November 5, 1996 from FDH to the other subcontractors (FDH 1996) lays out the sitewide coordination responsibilities for FDH and RFSH for environmental monitoring (Table 4). Another example is the system of environmental compliance officers (ECOs) that represent all the facilities and projects on environmental compliance issues. The ECOs meet weekly to share compliance strategies, etc. The ECO meetings can be used to share new requirements, such as 10 CFR 834, and to coordinate a consistent strategy for implementation for all contractors. 
Table 4. Coordination of Sitewide Air \& Water Activities Within the PHMC.

2

\begin{tabular}{|c|c|c|c|}
\hline $\begin{array}{l}\text { Effluent and Environmental } \\
\text { Monitoring Activity }\end{array}$ & $\begin{array}{l}\text { Fluor Daniel } \\
\text { Hanford, Inc. } \\
\text { Contact }\end{array}$ & $\begin{array}{l}\text { Rust Federal } \\
\text { Services of } \\
\text { Hanford } \\
\text { Contact } \\
\end{array}$ & $\begin{array}{l}\text { U.S. Department of } \\
\text { Energy, Richland } \\
\text { Operations Office } \\
\text { Contact }\end{array}$ \\
\hline $\begin{array}{l}\text { Efluent and environmental . } \\
\text { monitoring program management }\end{array}$ & KJ Svoboda & DL Mitchell & Suzanne E. Clarke \\
\hline $\begin{array}{l}\text { Effluent reporting } \\
\text { (radioactive) }\end{array}$ & JA Bates & BP Gleckler & $\begin{array}{c}\text { Hector M. Rodriguez } \\
\text { Suzanne E. Clarke }\end{array}$ \\
\hline $\begin{array}{l}\text { Effluent reporting } \\
\text { (nonradioactive) }\end{array}$ & KA Peterson & RE Johnson & Hector M. Rodriguez \\
\hline $\begin{array}{l}\text { National Emission Standards for } \\
\text { Hazardous Air Pollutants Federal } \\
\text { Facility Compliance Agreement }\end{array}$ & JA Bates & WE Davis & $\begin{array}{l}\text { Hector M. Rodriguez } \\
\text { Suzanne E. Clarke }\end{array}$ \\
\hline $\begin{array}{l}\text { Radiation protection } \\
\text { (environmental monitoring plan, } \\
\text { facility effluent monitoring plans, } \\
10 \text { CFR 834) }\end{array}$ & JA Bates & $\begin{array}{l}\text { LP Diediker } \\
\text { DW Fritz }\end{array}$ & $\begin{array}{l}\text { Dana C. Ward } \\
\text { Roger C. Briggs }\end{array}$ \\
\hline Near-field monitoring & JA Bates & $\begin{array}{c}\text { JJ Dorian } \\
\text { AR Johnson }\end{array}$ & Dana C. Ward \\
\hline
\end{tabular}

\begin{tabular}{|c|c|c|c||}
\hline $\begin{array}{c}\text { Harford Environmental } \\
\begin{array}{c}\text { Managernent Program } \\
\text { Activity }\end{array}\end{array}$ & $\begin{array}{c}\text { Fluor Daniel } \\
\text { Hanford, Inc. } \\
\text { Contact }\end{array}$ & $\begin{array}{c}\text { Rust Federal } \\
\text { Services of } \\
\text { Hanford Contact }\end{array}$ & $\begin{array}{c}\text { U.S. Department of Energy, } \\
\text { Richland Operations Office } \\
\text { Contact }\end{array}$ \\
\hline Air Operating Permit & KA Peterson & BL Cum & Hector M. Rodriguez \\
\hline $\begin{array}{c}\text { Portable Temporary } \\
\text { Radioactive Airborne } \\
\text { Emission Units }\end{array}$ & JA Bates & DW Fritz & $\begin{array}{c}\text { Hector M. Rodriguez } \\
\text { Suzanne E. Clarke }\end{array}$ \\
\hline $\begin{array}{c}\text { National Pollutant Discharge } \\
\text { Elimination System } \\
\text { permitting and reporting }\end{array}$ & JJ Kapadia & $\begin{array}{c}\text { LP Diediker } \\
\text { JJ Luke }\end{array}$ & Alex E. Teimouri \\
\hline
\end{tabular}


1 The FDH team will continue to communicate with PNNL, BHI, and DOE-RL in an open and

2 timely manner. Particular emphasis will be placed on maintaining the relationships with BHI

The FDH team, along with BHI and PNNL, will actively participate in the DOE-RL Natural Resource Team meetings, quarterly environmental monitoring exchange meetings, and other routine and special meetings and interfaces. Environmental monitoring issues will be discussed promptly amongst the effected environmental monitoring groups and with DOE-RL.

The frequency of these ongoing routine meetings was reviewed and determined to be generally adequate when used in conjunction with other separate meetings scheduled to address specific environmental monitoring deliverables or issues. Communications could be improved, however, by increasing the frequency and formality of the quarterly environmental monitoring exchange meetings (refer to Quarterly Meeting Agenda). Other meetings cover site reports such as the Hanford Site Environmental Report and the EMP, new regulations such as 10 CFR 834, analytical services, the WDOH Quality Assurance Task Force, special surveys such as the recent aerial radiological survey of the Hanford Site performed by Bechtel Nevada.

Continued involvement and an active team role and participation by BHI and DOE-RL Environmental Restoration program representatives are vital to ensure that adequate pre-operational, operational, and post-remediation environmental monitoring (both near- and far-field) are performed for their environmental remediation activities.

2.2.2.2 Quarterly Meeting Agenda. The need to be informed of activities that effect effluent, near-field, and the far-field environment is noted as being very important. Because of the dynamics of the Hanford Site, the Quarterly EMP meetings did not fully meet the need of informing environmental monitoring contractors of activities in a timely fashion. With this in mind, the following schedule and agenda is recommended for the Quarterly Environmental Monitoring meetings:

- The frequency of the environmental monitoring informational exchange meetings should be increased from quarterly to bi-monthly. The EMP meetings should be scheduled for the second week of all even months.

- As a minimum, the following topics will be discussed at each scheduled meeting:

- events that may have impacted the environment

- current and future Notices of Construction, which are Clean Air.Act permits with WDOH and EPA

- the status of 10 CFR 834

- the status of the annual reports in progress

- highlights of all contractor activities (construction, cleanup, etc.).

A multi-contractor team has been identified to better document and agree on the purpose of these meetings, and to formalize standing agenda topics. 
2.2.2.3 Integrate Environmental Monitoring Schedules. This review was conducted to determine if integration of the environmental monitoring schedules for the FDH team, PNNL, and BHI would be feasible, cost effective, and beneficial to the environmental programs.

Currently, the following three documents control the environmental monitoring and sampling schedules on the Hanford Site.

- Routine Environmental Monitoring Schedule, Calendar Year 1997 (WHC 199d).

This document provides $\mathrm{BHI}$ and the $\mathrm{FDH}$ team a schedule in accordance with the WHC-CM-7-5, Environmental Compliance and BHI-EE-02, Environmental Requirements, of monitoring and sampling routines for the Near-Field Monitoring progrram during calendar year (CY) 1997.

- Statement of Work for Services Provided by the Waste Sampling and Characterization Facility for Effluent Monitoring during Calendar Year 1997 (HNF 1997).

This document defines the services the Waste Sampling and Characterization Facility (WSCF) provides EEM throughout the calendar year and identifies the samples EEM plaris to submit for analysis in CY 1997. Analysis of effluent (liquid and air discharges) and environmental (air, liciuid, animal, and vegetative) samples is required using standard laboratory procedures, in accordance with regulatory and control requirements.

- Environmental Surveillance Master Sampling Schedule (PNL 1995).

This document contains the planned 1996 schedules for routine collection of samples for the surface environmental surveillance project, drinking water project, and groundwater surveillance project.

Three separate programs currently monitor facility effluent and the surface environs; air, soil/sediment, vegetation, animals, and surface water. The effluent monitoring is implemented by RFSH, the near-facility monitoring is implemented by RFSNW, and the environmental surveillance program is under the direction of PNNL. Integrating the schedules for the sampling activities of the three organizations into one document could be done, but not all schedules need to be shared with all persons involved in the various schedules.

The separate "program" sections would require the same effort as currently being expended by the individual program managers. These separate program sections would be incorporated into a single document and published annually. Additional costs would be incurred incorporating the single document but this cost would be the greatest the first year, which would becorne a template for subsequent years.

The benefit of the single document would be as a single comprehensive reference for reggulators or public interest groups wanting to know about a sample event and/or to plan 
a surveillance activity around a sample activity. It could be cumbersome to the individual users as they would have unwanted information that could become confusing and possibly create sampling errors.

Weighing the these considerations, it would seem that leaving the schedules as published in separate documents would be the most practicable and most cost effective.

\subsubsection{Integration Plan for Coordinating Preparation of Annual Reports. All annual} reports currently are coordinated around the preparation of the HSER. The effluent data compilation and dose modeling are carefully scheduled to mesh with the Radiation Air Emissions (RAE) report, which requires doses to be calculated using the EPA approved CAP88 (EPA 1990), versus HSER, which uses GENII (PNL 1988). The effluent reporting and near-field monitoring program descriptions and data are summarized in the HSER. The more detailed information and data are included in the corresponding annual reports. The same personnel in PNNL and the FDH team have and should continue to support each other's annual reports alternately throughout the reporting season. There were no serious problems identified in the production schedules.

\subsubsection{Sharing Monitoring Procedures, and Databases. The sharing of sampling and} monitoring procedures most recently has occurred with the transfer of the 324 and 327 Buildings from PNNL to the FDH team. The procedures are specific for the methods and equipment, i.e., tritium and radon collection systems. The PNNL methods differ only slightly from past and present FDH team systems. The effluent data path is through the 325 Laboratory and easily is added to the ERS database. The only significant difference is the release calculation for radon that will need to be added to FDH team procedures, or installed in the ERS. The effluent data from BHI already is in the ERS database and the possibility of adding the rest of PNNL's 30 stacks offers some advantages in annual reporting.

Further evaluation has determined that the integration of effluent procedures, via a sitewide document, would require additional effort and funding. The perceived benefit is very small at this time. As a result, a sitewide effluent procedures document is not recommended.

The sharing of databases most likely would reduce the level of effort and help ensure program consistency. The FDH team's and BH's effluent data and the near-facility monitoring data currently are stored in the ERS database. The ERS database also performs radioactive effluent calculations for the annual reports, eliminating the need to use spreadsheets. Use of the ERS database has been offered to PNNL's effluent monitoring organization. The ERS database can accommodate PNNL's needs, if PNNL should choose the database. Figure 5 displays the process of laboratory results collected and reported by the ERS database.

2.2.2.6 Share Radiological Control Technicians. The sharing of RCTs is depends on the development of like sampling and training procedures. This was discussed with PNNL personnel and there was concern that this might create union issues, because of different Hanford Atomic Metals Trade Council contracts between PNNL and the FDH team. This suggestion probably is not practical to implement at this time. 


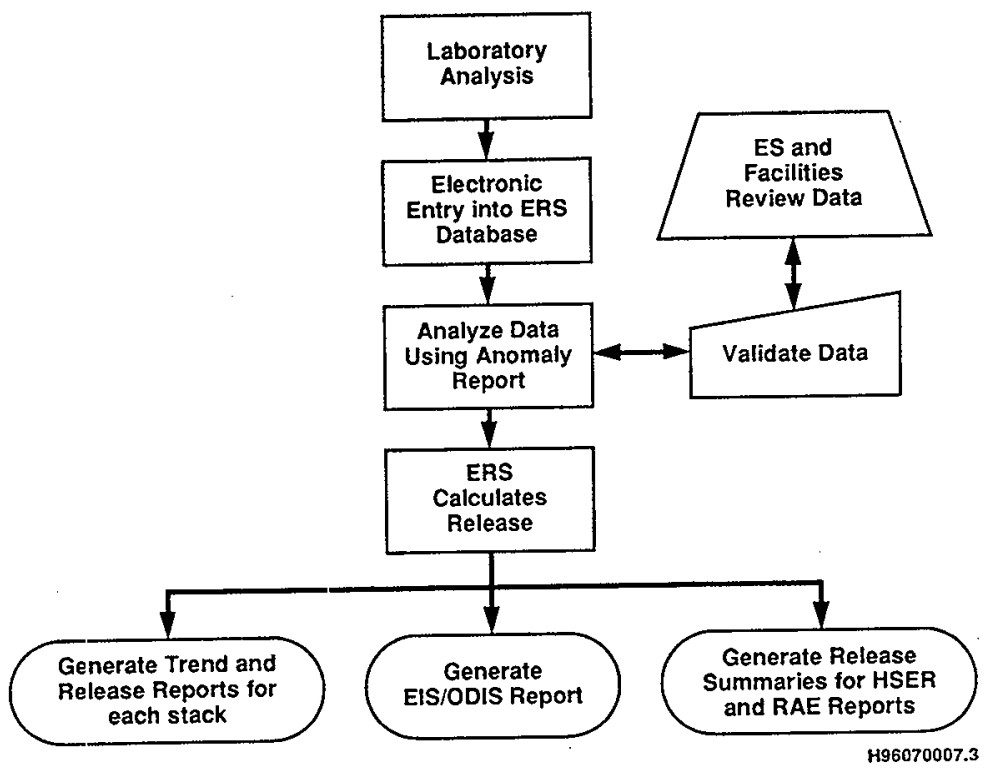

Figure 5. Environmental Release Summary Database. 


\subsubsection{Exchange or Borrow Technical Personnel. RFSH Air \& Water Services, RFSNW} Near-Field Monitoring, and PNNL staff will assist each other to the extent practical in completing short-term tasks when the implementing group requires additional expertise or staffing resources. The other companion environmental monitoring groups will be contacted and used to the extent practical, before contracting outside services. This has been done in the past to a certain extent. For example, RFSH Air \& Water Services has used RFSNW Near-Field Monitoring to perform nondestructive assays (NDA) using gamma spectrometry of high-efficiency particulate air (HEPA) filters for the 296-T-7, 296-S-15, and 296-A-10 stacks in support of NESHAP effluent sampling compliance evaluations. Another example is the teaming with BHI and PNNL to complete compliance activities for the NESHAP FFCA. Many joint efforts have been completed to deliver products to the EPA and WDOH [e.g., status reports, the memorandum of understanding (MOU), and new sampling methods].

Understandably, individual contractors will use their specialized expertise and resources within the scope of their site responsibilities, but will use companion organizations in other Hanford Site contractors for assistance. Such support is recommended and will be accomplished using work orders, task orders, or similar funding mechanisms.

\subsubsection{Integration Plan for Managing and Using Laboratory Services. The use of multiple} laboratories creates several logistical problems such as: (1) creating consistent statements of work, (2) ensuring analytical data are equivalent and comparable, (3) obtaining data in an electronic format consistent with the reporting database, and (4) dealing with multiple contracts/SOWs.

The easiest and most efficient method for managing and using laboratory services would be to consolidate all laboratory services into one contract or SOW. This might not be effective on a sitewide basis, because laboratory-to-customer relations are essential for communication and efficiency. Large contracts usually require a third party to manage the contract and to communicate with the laboratory. The recommendation is this would be more practical to integrate by primary contractor, rather than for the entire Hanford Site. The SOWs for Waste Sampling and Characterization Facility (WSCF) and the 325 Laboratory could benefit from some of the elements in the Quanterra SOW maintained by PNNL. The SOWs will be updated to reflect more of the requirements contained in the Quanterra SOW.

2.2.2.9 Collocation of Personnel. Collocation of staffing and equipment was considered, but it is recommended that this is not practical to pursue at this time. This conclusion is based on the other individual line management, program, and customer interfaces that need to be maintained and are company dependent. Basic company objectives and operating cost expectations are different for PNNL, BHI, FDH managed, and enterprise companies. To be competitive, enterprise companies like RFSNW will require less costly office accommodations, administrative systems, etc.

Specialized equipment will be shared to the fullest extent practical. Some equipment sharing or even transfers have occurred in the past between PNNL and what is now the FDH team. Examples include the transfer of both the equipment and responsibilities for radiological rail and 
HNF-MR-0535, Rev. 0

road surveys to the near-field moriitoring group from PNNL; and the loan of PNNL PM-10 air samplers to the FDH team for supporting special NESHAP and related diffuse and fugitive emissions monitoring.

The same monitoring protocols and equipment also will be used to the fullest extent practical. To a large degree this has been done in the past. For example, PNNL environmental dosimetry services and environmental dosimeters also are used for FDH-managed environmental monitoring. Standardized portable survey equipment is used on the Hanford Site that is serviced and calibrated by PNNL. Increased focus and emphasis will be placed on this aspect in the future.

2.2.2.10 Cross-Training of Personnel. The possibility of cross-training could entail sharing or loaning personnel for temporary periods to receive either formal classroom or less formal on-thejob training. It is recommended that cross-training or the sharing of training resources be pursued and implemented when cost effective and practical. A recent example of shared cross-training of PNNL and FDH team staff was vendor-provided training covering the use of a Fourier transform infrared (FT.IR) spectrometer for ambient air monitoring of volatile organic chemicals. These cooperative training arrangements will be used whenever possible in the future. Such arrangemerts will be essential to maintain the technical expertise of monitoring staffs under the tight budgets associated with the environmental monitoring activities.

\subsubsection{Basic Responsibilities of Each Major Contractor for Effluent and Environmental Monitoring Activities}

The EMP clescribes the effluent and environmental monitoring conducted by all three major Hanford Site contractors. For example, PNNL conducts sitewide environmental surveillance, sitewide groundwater monitoring, meteorology and climatology, and effluent monitoring of its facilities. As another example, the FDH team conducts near-field (near facility) monitoring and effluent monitoring of facilities. As a third example, the ERC (BHI) conducts all CERCLA monitoring, effluent monitoring of facilities it manages, and monitoring of optimization of design, conceptual model development, trending, point of compliance, and remediation performance evaluation activities. BHI has made arrangements for the FDH team to provide near-field monitoring and reporting services for the current fiscal year. Where these arrangements have been made, the organization responsible for performing monitoring is identified in detailed descriptions in the appropriate section of the EMP.

The detailed responsibilities of the primary Hanford Site contractors will need to be described in the EMP (DOE/RL 91-50) to reflect the changes in responsibilities that occurred as a result of the PHMC, which became effective in October 1996. Introduction section of the upcoming revision of the EMP, to be completed by November 1997, will be enhanced to match the detailed description of the program responsibilities now in place for the three major contractors; and will be carried forward into the appropriate sections of the EMP. 


\subsubsection{Description of Existing Environmental Programs with Responsibilities Related to Sitewide Integration Among Contractors and with Regulatory Agencies}

There are several existing environmental programs on the Hanford Site that demonstrate sitewide integration among the contractors and regulatory agencies. Several of these are as follows.

2.2.4.1 Hanford Environmental Dose Overview Panel. The HEDOP was established by the DOE-RL to promote consistency and defensibility of environmental dose calculations on the Hanford Site. The HEDOP has the responsibility for defining standard, documented computer codes and input parameters to be used for radiological dose calculations for the public in the vicinity of the Hanford Site. Only those procedures, models, and parameters previously defined by the HEDOP are used to calculate the radiological doses for reporting in the Hanford Site annual report.

2.2.4.2 Quality Assurance Task Force. The QA Task Force is an advisory group to the WDOH. It is composed of governmental and industrial organizations responsible for monitoring the effects of radiation on the environment. Task Force members use their expertise to ensure that environmental radiation data are of the highest quality.

The Hanford Working Group is one committee of the QA Task Force and is staffed by Task Force members who perform environmental radiation monitoring on, and around, the Hanford Site. Members of this committee work together to assess radiological environmental monitoring data. The group compares radiological environmental monitoring data for locations on and around the Hanford Site; discusses Hanford Site-specific issues, draws conclusions, makes recommendations, and, when appropriate, takes actions. The group promotes the cooperation, coordination, and communication among the environmental radiation programs monitoring on, and around, the Hanford Site. The Hanford Working Group members include: WDOH, DOE-RL, PNNL, RFSNW EnvironmentaI Monitoring and Investigations, Washington Public Power Supply System, US Ecology, Inc., Seimens Nuclear Power, ATG Corporation, and the Oregon State Health Department.

Since 1985, the Hanford Working Group has coordinated approximately a dozen intercomparison studies based on Hanford Site samples or measurements. Samples are collected, split, and analyzed by the members and a public interest group representative. If results are not consistent, the group evaluates the problem and makes recommendations for long-term solutions.

\subsubsection{Fluor Daniel Hanford, Inc., Environmental Integration Group. The FDH} Environmental Integration (EI) group is currently the single point of contact for Hanford Site contractors for DOE Hanford Site inspections and audits by the regulatory agencies, except for CERCLA sites. The FDH/EI group receives all requests from the regulatory agencies for inspections and audits, and coordinates these with DOE-RL and the delegated contacts in RFSH and with the responsible Hanford Site contractor. 
The FDH/EI group also reviews and revises the FDH environmental policy directives manual (WHC 1996a) and other documents to ensure that the affected contractors and/or subcontractors are aware of changes to their work scope and responsibilities. Review, analysis, and responses to proposed rulemaking and decisions involving environmental regulations also are conducted by $\mathrm{FDH} / \mathrm{EI}$ group to ensure that final rules are analyzed and incorporated into policy documents to ensure compliance.

\subsubsection{Criteria Used to Establish $\downarrow$ and Measure Effluent and Environmental Monitoring Activities}

The criteria used to establish and measure EEM activities are described in the following sections.

\subsubsection{Criteria Used to Ensure Consistency Without Duplication Among Contractors.}

The responsibilities and criteria used to establish and ensure consistency without duplication of effluent and near-field environmental monitoring and surface environmental surveillance activities are included in the EMP.

Specific criteria used utilized for radiological effluent and environmental monitoring activities are included in "Environmental Regulatory Guide for Radiological Effluent Monitoring and Environmental Surveillance" (DOE/EH-173T). Radionuclide air emissions on the Hanford Site are monitored and reported, and dose calculations performed, in accordance with criteria included in "National Emission Standards for Emissions of Radionuclides Other than Radon from Department of Energy Facilities" (40 CFR 61, Subpart H) and "Radiation Protection-Air Emissions" (WAC 246-247). Hanford Site sources are currently being evaluated for meeting the procedural requirements for flow measurement, emissions measurement, QA, and sampling documentakion.

Where required by FEMP determinations, facility-specific FEMPs are prepared using documented guidance (WHC 1992). FEMPs include a discussion of the design criteria and technical specifications pertaining to the effluent monitoring/sampling systems, including alternate monitoring and assessment methods when different from those specified by the EPA and the DOE 5400-series Orders.

In accordance with Clean Air Act requirements, National Pollutant Discharge Elimination System (NPDES) permitted liquid discharges are monitored and reported per requirements included in Permit No. WA-000374-3 (NPDES 1981). Nonroutine monitoring for nonradioactive constituents [as defined by the Resource Conservation and Recovery Act (RCRA) of 1976] are covered in the sampling analysis plans (SAPs). Unplanned releases are evaluated and reported by FDH/EI in accordance with requirements of CERCLA, NPDES, NESHAP/WAC, and DOE Order 232.1.

\subsubsection{Effluent and Environmental Monitoring Standards of Measurement and}

Reporting. The EMP contains details or specific references to the rationale and design criteria 
1 for the extent and frequency of monitoring and measurements, procedures for laboratory analyses, QA requirements, and program implementation procedures.

The HSER is prepared anmually pursuant to DOE Order 5400.1. The report summarizes environmental monitoring data that characterize Hanford Site environmental management performance and demonstrated compliance status. More detailed environmental compliance, monitoring, surveillance, and study reports that might be of value are referenced in the text of the HSER to the extent practical. Examples of such reports include the radionuclide air emissions report, the FDH annual environmental release report, monthly NPDES report, annual operational environmental monitoring report, nonradioactive air emissions report, etc. Reporting formats for these other reports are in accordance with the specific regulatory requirements when applicable. For the routine monitoring reports where formats are not specifically dictated by regulatory requirements, the reports are prepared in accordance with DOE/EH-0173T where applicable, consistent with the environmental monitoring report. Reports covering special monitoring and studies are prepared in accordance with contractor guidelines and good engineering practices..

\subsubsection{Methods for Documenting Decisionmaking, and How to Enforce the Solutions or Policies}

The FDH team decisionmaking process is conducted such that direction and policy decisions flow down and alternative implementation approaches flow up as discussed in the following section and, as illustrated in Figure 6 . This two-way information flow draws maximum benefit from corporate best-in-class capabilities. Enforcing the solutions and policies also is discussed in this section.

2.2.6.1 Methods for Decisionmaking. The key functions in the decisionmaking process are (1) subcontractor development of alternatives and (2) FDH analysis of alternatives. The subcontractors have access to the integrated sitewide baseline to perform 'what-if' analyses. The subcontractor submittal of alternatives to FDH include the following:

- Scope, cost, and schedule information

- ES\&H, technical, schedule, and cost impacts

- Risk mitigation plans

- Compliance recommendations

- Preferred alternatives with justification.

FDH reviews the subcontractor's submittals and analyzes the impact of the preferred alternative on the integrated sitewide baseline. FDH also considers inputs from DOE-RL, stakeholders, regulators, and independent experts. If a proposed alternative is detrimental to the integrated sitewide baselining, FDH works with the subcontractor (or other major contractors) to develop an acceptable solution.

FDH determines the effects of the alternatives on the integrated sitewide baseline. Decisions affecting technical, cost, or schedule baselines are made by FDH with DOE-RL concurrence. 


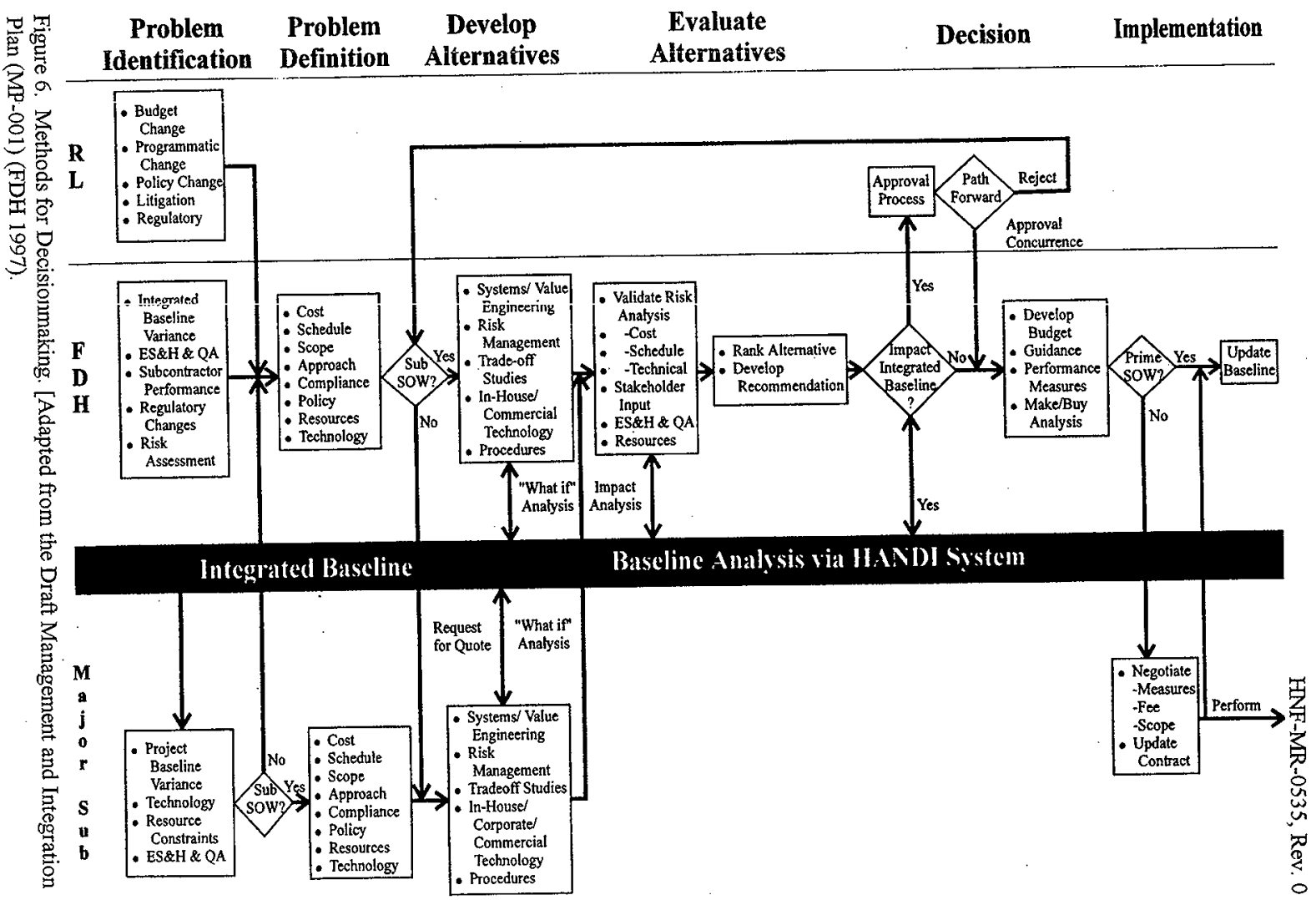


1 Decisions requiring formal Change Control Board action are forwarded to DOE-RL using

2 approved procedures.

3

Once decisions are made, FDH implements these decisions through contract action with the affected subcontractors. Requirements are added, amended, or modified to incorporate the effects of the decision using the subcontract change mechanisms.

\subsubsection{Enforcing the Solutions and Policies. FDH has committed to defining projects and} performance standards, and contracting with best-in-class companies to perform to those standards. Details of these commitments currently are being documented in the Draft Management and Integration Plan, MP-001 (latest draft dated February 11, 1997) (FDH 1997). FDH will hold subcontractors responsible for running their projects as they do their businesses. FDH environmental policies and procedures, for compliance by the subcontractors, are distributed in the FDH environmental compliance manual (WHC 1996a). The effluent and environmental activities will be performed largely by RFSH and RFSNW, with formal documentation, i.e., reports, plans, and SOWs, etc. being reviewed and approved by FDH. The facilities routinely will require permitting for nonroutine activities or modifications to their facility or its effluent monitoring systems. The transmittal of these requests for permits is made to DOE-RL, only after review and approval by the designated FDH POC. FDH will perform oversight of the environmental monitoring activities performed by RFSH and RFSNW through the Facility Evaluation Board (FEB). This also will include the comprehensive auditing of individual facilities by the FEB for compliance with all environmental regulations and the FDH environmental policies.

The next level of oversight is performed by DOE-RL. At the present time this consists of field surveillances of various EEM activities. In addition, DOE-RL reviews for approval, any formal compliance documentation or external publications that will be sent to other regulatory agencies. This will typically includes annual reports and SOWs with the analytical laboratories.

Further oversight on radioactive air emissions is provided by the EPA, Region 10, and the WDOH. These agencies enforce compliance with the Clean Air Act (40 CFR 61, Subpart H), and the WAC 246-247, respectively. Frequent visits by the WDOH require almost continuous interaction and compliance self-assessment by facilities and the central environmental organizations that compile the sitewide reports for demonstrating compliance with the regulations. 
HNF-MR-0535, Rev. 0

\subsection{SCHEDULE}

2

3

4

5

6

7

8

\begin{tabular}{|c|l|l|}
\hline & \multicolumn{1}{|c|}{ Activity } & \multicolumn{1}{|c|}{ Date } \\
\hline 1. & Inform FDH, BHI, PNNL points of contact & Complete \\
\hline 2. & Update Environmental Monitoring Plan & October 31,1997 \\
\hline 3. & Update Quality Assurance Program Plans & July 31, 1997 \\
\hline 4. & Update Laboratory Statements of Work & June 30, 1997 \\
\hline 5. & $\begin{array}{l}\text { Past Program Reviews. The FDH team will continue to } \\
\text { communicate with it's subcontractors, BHI, and PNNL through } \\
\text { the rolutine meetings. }\end{array}$ & Complete \\
\hline 6. & Change frequency of routine meetings. & April 30, 1997 \\
\hline 7. & Provide new meeting agenda. & April 30, 1997 \\
\hline
\end{tabular}


HNF-MR-0535, Rev. 0

This page intentionally left blank. 


\subsection{REFERENCES}

DOE/EH/OEV-05-P, Environmental Survey Preliminary Report, Hanford Site, Richland, Washington, August 1987, U.S. Department of Energy, Washington, D.C.

DOE/EH-0139, draft Tiger Team Assessment of the Hanford Site, 1990, U.S. Department of Energy, Washington, D.C.

DOE/EH-0173T, Environmental Regulatory Guide for Radiological Effluent Monitoring and Environmenial Surveillance, 1991, U.S. Department of Energy, Washington, D.C.

DOE Order 232.1, Environmental, Safety, and Health Reporting, U.S. Department of Energy, Washington, D.C.

DOE Order 5400.1, General Environmental Protection Program.

DOE Order 5400.5, Radiation Protection of the Public and Environment.

DOE Order 5484.1, Environmental Protection, Safety, and Health Information Reporting Requirements.

DOE Order 5820.2A, Radioactive Waste Management.

DOE/RL-9.1-50, Environmental Monitoring Plan (EMP) United States Department of Energy Richland Operations Office, Rev. 1, 1994, Richland, Washington.

Ecology, E].A, and DOE-RL, 1996, Hanford Federal Facility Agreement and Consent Order, Washington State Department of Ecology, U.S. Environmental Protection Agency, U.S. Department of Energy, Richland Operations Office, Olympia, Washington, amended periodically.

EPA, 1990, The Clean Air Act Assessment Package-1988 (CAP88), A Dose and Risk Assessment Methodology for Radionuclide Emissions to Air, Vois. 1-3, U.S. Environmental Protection Agency, Washington, D.C.

FDH, 1996, letter dated November 5, 1996 from FDH to subcontractors: "Sitewide Coordination Responsibilities for FDH and RFSH for Environmental Monitoring", Fluor Daniel Hanford, Inc., Richland, Washington.

FDH, 1997, Draft Management and Integration Plan, MP-001, Fluor Daniel Hanford, Inc., Richland, Washington. 
1 HNF, 1997, Statement of Work for Services Provided by the Waste Sampling and Characterization Facility for Effluent Monitoring during Calendar Year 1997, HNF-EP-0835-2, Richland, Washington.

ISO, 1996, ISO 14000 Standards, International Organization for Standardization, Geneva, Switzerland.

NPDES, 1981, National Pollutant Discharge Elimination System Permit No. WA-000374-3 (covers two liquid discharges: $100-\mathrm{N}$ and $-\mathrm{K}$ Areas).

PNL, 1988, GENII - The Hanford Environmental Radiation Dosimetry Software System, PNL-6584, Pacific Northwest Laboratory, Richland, Washington.

PNL, 1995, Environmental Surveillance Master Sampling Schedule, PNL-10950, Pacific Northwest Laboratory, Richland, Washington.

PNNL, 1996, Contract 163589 - Sixth Operational Year Statement of Work Effective July 15, 1996, Pacific Northwest National Laboratory, Richland, Washington.

WHC, 1993, Operational Environmental Monitoring Manual, WHC-CM-7-4, Westinghouse Hanford Company, Richland, Washington.

WHC, 1992, A Guide for Preparing Hanford Site Facility Effluent Monitoring Plans, WHC-EP-0438-1, Westinghouse Hanford Company, Richland, Washington.

WHC, 1996a, Environmental Compliance Level II Policy Manual, WHC-CM-7:5, Westinghouse Hanford Company, Richland, Washington.

WHC, 1996b, Environmental Support FY 1997 Multi-Year Work Plan WBS 1.5.2, WHC-SP-1 112, Revision 2, Westinghouse Hanford Company, Richland, Washington.

WHC, 1996c, Statement of Work for Analytical Services Provided by the PNNL Analytical Laboratory (325 Lab), WHC-EP-0857-1, Westinghouse Hanford Company, Richland, Washington.

WHC, 1996d, Routine Environmental Monitoring Schedule, Calendar Year 1997, WHC-SP-0098-8, Westinghouse Hanford Company, Richland, Washington.

Hanford Site Self-Assessment was issued April 20, 1990 (9001817B).

Operational Environmental Monitoring Program Self-Assessment (\#9357245) issued April 6, 1993.

WHC Operational Environmental Monitoring Program (\#88700-93-JWS) issued October 29, 1993. 
HNF-MR-0535, Rev. 0

\section{APPENDLX A \\ EFFLUENT AND ENVIRONMENTAL MONITORING SELF-ASSESSMENT}

In FY 1995, a Self-Assessment was conducted of WHC's Effluent Monitoring and Operational Environmental Monitoring Programs. The assessment was conducted to measure progress towards coming into compliance with findings and suggestions from past audits and surveys such as the DOE.HQ Environmental Survey of 1986 (also known as the 'Mary Walker Survey'), the Tiger Team Audit, and the DOE-HQ EH-24 Environmental Audit. Impact to the existing environmental monitoring program was not significant, even though room for improvement in implementation and communication among contractors always exist.

This self-assiessment was conducted to improve compliance and reduce duplication even though the FY 1994 DOE-HQ EH-24 environmental audit credited the Operational Environmental Monitoring and Effluent Monitoring Programs for having "performed thorough self-assessments" (refer to "Routine Environmental Audit of the Hanford Site Richland, Washington,"

$\mathrm{DOE} / \mathrm{EH}-0403$, paragraph 3.7 .1 ) that regularly monitor these goals.

The following tasks were identified and the status of each is identified in italics following the task:

- Perform a study of diffuse sources and their emission potential.

This task is on going and budgeted as part of NESHAPs compliance. Two reports have been published to date with additional studies funded and scheduled.

- Identify potential sources of volatile organic emissions from a comprehensive review of existing data.

This task is ongoing and budgeted. The PNNL managed Surface Environmental Monitoring Progrem has included hazardous chemical monitors at certain key air samplers. Other hazarilous waste monitoring is conducted by various contractors at specific projects and information is shared at DOE-RL sponsored Quarterly Technical Exchange Meetings.

- Provide recommendations for evaluating biological transport of radioactive contamination on and adjacent to facilities and waste handling, storage, and disposal sites.

This tusk is ongoing as budgets allow but is not routinely funded. Permanent sampling locations have been selected and samples collected in 1995 and 1996 in the 200 Areas with other areas to follow as budgets allow. 
- Document the status of outdoor radioactive surface contamination on the Hanford Site. The document, "Status of Outdoor Radiological Contamination at the Hanford Site" has been issued to assist all contractors in cleaning up contaminated sites. A schedule with input from all involved contractors is published yearly and a quarterly report summarizes the status of surface and underground contamination.

- Review training requirements and policy implementation.

Training is monitored, scheduled, and updated regularly; required courses are provided sitewide by the different contractors to avoid duplication. Required training is tracked within each contractor organization and scheduled as necessary. Examples include intercontractor provision of respiratory protection (mask fits provided by Hanford Environmental Health Foundation to all Hanford Site contractors followed by hands-on training provided during hazardous materials management and emergency response training), radiological protection training (Hanford Technical Training Center operated by DynCorp), hazardous waste worker training (provided at the Hazardous Materials Management and Emergency Response facility operated by FDH using instructors from various contractors), and habitat evaluation procedures (offered through PNNL by instructors brought in for the duration of the course).

- Management assessments should focus on how well the integrated QA program is working and should identify management problems that hinder the organization from achieving its objectives in accordance with quality, safety, and environmental requirements.

The quarterly technical exchange meetings, hosted by DOE-RL EAP, with the various contractors represented, allow the managers to verify integration, where appropriate, throughout the Hanford Site.

- Provide input, concurrent with PNNL, to improve and update the EMP before the required date of November 11, 1994 as specified in DOE Order 5400.1.

The EMP was updated on schedule to reflect changing contractor (BHI) roles on the Hanford Site. The EMP is scheduled for update by November 1997 to reflect continued changes in contractors (i.e., FDH and subcontractors).

- Interface with facility ECOs to evaluate compliance issues in accordance with agreed upon schedules.

All facilities have ECOs within the internal management system and meetings to discuss common problems and lessons learned are held regularly.

- Manage the OEMP, including tasks in five areas (General Environmental Studies, Nonradioactive Air Monitoring, Effluent Monitoring System Line Loss Studies, Routine 
HNF-MR-0535, Rev. 0

Operational Environmental Monitoring, and Special Operational Environmental Monitoring) in accordance with DOE requirements for the Hanford Site.

The OEMP is operated in accordance with DOE requirements (DOE/EH-0173T). Nonradioactive air emission monitoring studies and line loss studies have been completed and appropriate changes made.

- Query customers to determine level of satisfaction with services provided by the various environmental organizations.

Questionnaires to determine satisfaction with services provided by the environmental organizations hove been circulated to each customer and are used to implement needed changes.

- Complete and document the results of implementation of chartered responsibilities to ensure no holes developed as the result of new contractor transition.

Assurance that all contractors are in compliance with appropriate regulations, avoiding duplication, and sharing of technical information is accomplished through the quarterly technical exchange meeting of the EMP. representatives. The meeting is chaired by $D O E$ $E A P$ and attended by representatives from PNNL, BHI, and the FDH team.

- Review and update the QAPP to ensure quality of environmental sample data.

The OEMP $Q A P P$ is reviewed annually and updated as needed. 
This page intentionally left blank. 
HNF-MR-0535, Rev. 0

\section{APPENDIX B}

\section{DOE-HQ/EH-24 AUDIT SUMMARY}

In May of 1994, the Office of Environmental Audit (EH-24) conducted a routine environmental audit of the Hanford Site. There were no findings directed towards the WHC OEMP under the direction of 'EES. In fact, there was praise given to EES for their point-by-point justification of rationale for surface water sampling points as part of self-assessment response actions and thorough self-assessment of the OEMP against the DOE Regulatory Guide DOE/EH-0173T. The WHC goals to maintain an exceptionally high quality of formal documentation, both in procedures and QA, was among the best in DOE.

\section{Key Findings}

- Environmental Program Integration. There is not adequate integration and/or coordination of many environmental management activities among the contractors and DOE-RL.

- Program Oversight and Control. There is inadequate oversight and control of the Hanford environmental program by DOE-RL.

The audit team did find several areas that required integration of programs or where duplication of programs were evident. Examples of areas that supported the need for programmatic integration included the following.

- Hanford Site waste minimization required semiannual reporting that was done by WHC. However, each of the contractors maintained pollution prevention awareness programs as well as standalone procedures.

- The groundwater monitoring activities were performed under multiple programs by multiple organizations.

- The groundwater monitoring programs had not fully integrated sampling efforts to identify joint sampling opportunities to reduce costs and to minimize purgewater and to investigative derived wastes.

- There was not a clear and consistent justification of monitoring wells owned and sampled by the separate programs.

- The public and regulators have expressed concern that there is no single entity on the Hanford Site responsible for groundwater issues and strategy. 
- Although the Hanford Training Council was working to develop a comprehensive, integrated training program, many of the environmental training activities remained to be integrated.

- DOE-RL and the contractors had not implemented an environmental as low as reasonably achievable program for comprehensive evaluations of activities and facilities.

- At least three separate, contractor-developed tracking systems operated on the Hanford Site and DOE-RL managers appeared to borrow from all three, depending on the specific area of oversight.

- Poor communications within environmental programs resulted in two examples of potential or perceived redundancy with the sitewide water table measurements by both PNNL and WHC and the completion of separate sitewide groundwater models by PNNL and WHC.

- A comprehensive, integrated self-assessment program that involves all levels of organization had not been developed.

The last of the remedial activities were completed by September 1995 . 
HNF-MR-0535, Rev. 0

\section{APPENDIX C \\ DOE-HQ TIGER TEAM ASSESSMENT}

In June 1989, the U.S. Secretary of Energy announced a 10-point initiative to conduct independent oversight compliance and management assessments of the ES\&H programs at DOE facilities. To implement that plan, a Tiger Team consisting of individuals knowledgeable in ES\&H activities was assembled. In anticipation of this event, the DOE-RL Manager initiated a Hanford Site self-assessment in November 1989 to identify current ES\&H conditions before the Tiger Team visit. The Hanford Site self-assessment was issued April 20, 1990 (9001817B) and identified three major causes for existing problems; aging facilities, major changes resulting from the consolidation from eight contractors to four, and a history of inadequate discipline in planning analysis and corrective action. The Tiger Team Assessment was conducted from May 21, 1990 to July 18, 1990, and a draft report was issued (DOE/EH-0139).

\section{TIGER TEAM FINDINGS}

The primary findings of the Tiger Team assessment were that the Hanford Site was in "a positive improvement slope, but far from achieving ES\&H expectations or excellence." The primary reasons were contractor changes, anxiety over jobs, negative public and political comments, a new mission, etc. In summary, "these simultaneous changes have been a substantial challenge for Hanford leadership..." "Adding to management's challenge is an increasingly demoralized work force." Many of these same problems exist today, 7 years later. The assessment identified a total of 105 findings and 266 concerns, none of which warranted a cessation of activities.

\section{Specific Findings}

With regard to WHC Environmental Monitoring, a number of findings were called out, many of which required integration efforts with the other prime contractors, PNNL and ICF Kaiser Hanford Company. Examples of those that warranted major attention were as follows:

- $\mathrm{A} / \mathrm{CF}-1$

- A/CF-5

- A/BMPF-2

- A/BMPF-3

- A/BMPF-4

- A/BMPF-8

- RAD/CF-1

- $\mathrm{RAD} / \mathrm{CF}-4$

- SSB/CF-1
Effluent Stack sampling deficiencies

Air emissions from U-Plant

Absence of an air emissions inventory

Line losses in sampling systems

Ambient air monitoring deficiencies

Releases exceeding WHC internal guidelines

Deficiencies in the WHC and PNNL radiological monitoring programs

Hanford dose assessments are not based on current land use data

Radioactivity contaminated soil control program deficiencies. 
Examples of other findings that were more easily correctable or only peripherally involved WHC Environmental Monitoring included the following:

- A/CF-3 Fugitive dust emissions from ash storage areas

- A/CF-6 Registration of airborne sources

- A/BMPF-7 HEPA Filter program deficiencies

- SW/CF-2 Incomplete information of NPDES permit application

- SW/CF-4 Discharge of sewage to the ground

- SW/CF-7 Incomplete sampling protocols

- SW/BMPF-1 Contradictory records retention requirements

- SW/BMPF-2 Inadequate monitoring of drinking water at point of use

- SW/BMPF-3 Inadequate review of the NPDES discharge monitoring reports

- WM/BMPF-1 Outdoor storage of waste equipment with smearable contamination

- WM/ICF-6 Noncompliance with DOE Order 5820.2A, Radioactive Low-Level Waste Management

- QA/CF-4 Deficiencies in the PNNL oversight of the U.S. Testing Contract

- QA/CF-1 Chain-of-custody procedure not being followed completely

- QA/CF-2 Deficiencies in the WHC surface water sample collection program

- $\mathrm{RAD} / \mathrm{CF}-2$ Decontamination and decommissioning program deficiencies

- IWS/CF-1 Incomplete characterization and tracking of inactive waste sites

- IWS/BMPF-2 Incomplete distribution of annual environmental report.

With regard to broader management issues that impacted WHC Environmental Monitoring, these included the following:

- $\mathrm{M}-3$

- $\mathrm{M}-4$

- $\mathrm{M}-7$
Tri-Party Agreement program management ES\&H prioritization and implementation plan Inefficient use of resources. 


\section{RESPONSE}

With regard to some of the Tiger Team findings, an immediate response was provided when contractor management considered that there was an error in the assessment, an issue had not been adequately reviewed, or the scope and/or the mandate for correction resided solely with DOE. For most of the other findings, response and correction systems were set up to deal with each finding. These included the QUEST (audit monitoring system), certification of corrective action completion, action plan re-assessments (which included budget planning), and progress assessment issued by DOE-HQ in April 1992.

With regard to WHC Environmental Monitoring, a number of the findings were resolved in revisions to the Operational Environmental Monitoring Manual (WHC 1993), which addressed numerous issues related to air monitoring protocols, integration with PNNL, chain-of-custody requirements, sampling and reporting procedures, instrument calibration, etc. A follow-up effort of significance was the issuance of the Operational Environmental Monitoring Program SelfAssessment (\#9357245) issued April 6, 1993. This document identified the compliance status of mandatory requirements promulgated by the Environmental Regulatory Guide for Radiological Effluent Monitoring and Environmental Surveillance (DOE/EH-0173T) with the existing programs. This self-assessment identified areas where improvements or changes were needed in technical adequacy, best management practices, integration with PNNL staff, interfaces with DOE-RL, and reduction in overlapping aspects of monitoring programs.

Another effort in response to the Tiger Team findings and self-assessments was the review of the WHC Operational Environmental Monitoring Program (\#88700-93-JWS) issued

October 29, 1993. The principle thrust of this review was to document the technical rationale for specific sample locations as identified in RAD/CF-1. Also, some minor areas of duplication with PNNL were identified and corrected by the close of CY 1993.

One of the final issues to be closed out was finding A/BMPF-3 concerning line losses in sampling systems. Final action represented closure on all the Tiger Team technical findings that were the responsibility of the WHC Environmental Monitoring Programs.

\section{SITE/CONTRACTOR INTEGRATION}

While the Tiger team findings based on specific technical issues have all been resolved, generic issues that were more convoluted and affected or involved the Hanford Site as a whole have been more difficult to manage. Site/contractor integration is one of these issues. The reasons cited for difficuity in achieving excellence were contractor changes, anxiety over jobs, negative public and political comments, and low worker morale, which are still afflicting the work force today. One of the major difficulties cited in the Tiger Team report was the consolidation of eight contractors to four and the inherit problems associated with that change. Now, in 1997, the Hanford Site again is challenged by contractor changes of a greater magnitude, going from four contractors to as many as 10, plus enterprise companies. As stated in the Tiger Team findings, "Hanford's need for monitoring and controlling their environmental program in the future will be essential," 
1 A major concern of the Tiger Team was that with the resource constraints (money and manpower), the scope (entire Hanford Site), complexity, and "number of organizational entities involved" (four contractors), there was still no plan to develop an integrated sitewide ES\&H Plan. At the time, WHC and PNNL accepted the challenge to integrate their programs and reduce overlap with a MOU. With the advent of the ERMC and the numerous contractor represented by the PHMC, the need for an integrated plan is even more essential to ensure that monitoring and surveillance are not fractured into a plethora of small entities. There are a number of specific areas where the more pervasive aspects of integration for ES\&H activities are needed and will be even more vital in the near future. These include the following issues identified by the Tiger Team findings.

- Long-term storage of radioactive and mixed wastes at the tank farms and low-level burial grounds potentially threaten the environment.

- Radioactive contaminated soil is spreading faster than it is being cleaned up.

- Clear accountability has not been established for program management.

- DOE-RL has no strategic management plan.

- Hanford Site contractors have not conducted regular, critical, self-appraisals of activities.

- Deficiencies in monitoring and characterizing exposure to toxic chemicals and physical agents.

- The integration and prioritization of ES\&H activities are inadequate.

- Management's ability to achieve ES\&H goals is inhibited by inadequate monitoring assessment and corrective action implementation.

- There is no sitewide integrated approach to surface decontamination, stabilization and remedial actions.

- Use of resources is inefficient.

- The multitude of ES\&H goals necessitates an effective prioritization effort, but past monitoring and appraisal efforts have not expected excellence.

- The lack of an integrated approach by all contractors for laboratory contracts including QA/QC procedures, data compatibility, etc.

- The impact on the environment from each facility should be minimized. 
- The integrated approach is lacking with regard to biological agents (i.e., vectors of disease).

- No QA program and inadequate integration of health hazard monitoring.

- Integration of monitoring for nonradiological hazardous wastes.

- The Hanford Site does not have an updated, fully-integrated soil contamination control program plan that takes into account programmatic responsibility, initial determination procedures, etc. As a result of not having a comprehensive, integrated procedural system, inconsistent methodologies are occurring in various HP field operations.

- There are no physical barriers or design features in place at cribs, ponds, or ditches to deter land and/or burrowing animals and birds from entering facility perimeters in order to minimize the spread of contamination or biotransport of radioactively-contaminated material. Evidence that transport of these materials continues to migrate beyond posted areas consists of radioactively-contaminated animal feces, urine, and tumbleweeds, which are removed as discovered.

- DOE-RL should distribute all contractor's Annual Environmental Reports to all local, state, federal agencies, and Hanford Advisory Board members, as well as to individuals with significant interests in operations and environmental impacts.

- No single environmental document (whether an environmental impact statement or other publicly available analysis) provides a comprehensive assessment of the environment of the Hanford Site. Nonradiological impacts, including both hazardous and nonhazardous materials, may not have been as comprehensively considered as possible in National Environmental Policy Act of 1969 documents. Some cumulative impacts (e.g., effects of hazardous materials, beneficial effects from continuing resource protection, and incremental effects of additional waste disposal) may be overlooked, undertreated, or unnecessarily quailtative.

- A sitewide ES\&H Prioritization and Implementation Plan would provide order when considering the magnitude of the Hanford Site mission and the need to integrate the interrelated activities of the five (now 10) organizations involved. Technical support at the Hanford Site comprises a large number of disciplines supplied by an even larger number of organizational elements.

- The dispersion of roles and responsibilities among the various DOE-RL contractors increases the number of players involved in any one activity, thus inherently increasing the opportunities for error and ultimately reducing efficiency and timeliness.

- There are a number of areas which would benefit from sitewide solutions to common problems. Currently, each contractor is approaching these problems separately, developing their own procedures and process which may not be consistent. This results 
in wasteful use of resources in the initial development and possibly the continued need for resources to cross train individuals on the differing systems that may result from the lack of a consistent approach. A sitewide system of establishing priorities against Hanford ES\&H objectives would more effectively direct resources.

Other issues that were not identified by the Tiger Team assessment, which will require continued and improved efforts with regard to Hanford Site integration, include environmental resource protection, issuance and implementation of the biological resources management plan, issuance and implementation and integration of the Hanford Site biological resources mitigation strategic plan and an integrated approach to potential lawsuits brought against the DOE and its contractors

11 with regards to concerns and issues such as those raised by the current 'Downwinders' legal 12 actions.

In summary, many of these issues currently are, and will continue to be, major concerns. Many of the complex integration issues addressed by the Tiger Team assessment in 1990 remain as challenges in 1997. The increase in the number of contractors will certainly present a continuing challenge. The following summary statement from the Tiger Team assessment document certainly applies to future efforts.

"The extensive acreage of contaminated soil and the inability to prevent migration of radioactivity to uncontaminated areas will require commitment of extensive resources in the future."

That statement appears true for many of the issues to be resolved to ensure excellence in the current mission for the Hanford Site. 
HNF-MR-0535, Rev. 0

\section{APPENDIX D \\ DOE-HQ MARY WALKER SURVEY}

The Action Plan is a report of the status of remedial actions taken to correct the 58 findings reported in Environmental Survey Preliminary Report, Hanford Site, Richland, Washington, DOE/EH/OEV-05-P, August 1987, which resulted from the Environmental Survey conducted from August 8 through September 5, 1986 by the DOE-HQ. The 58 findings were grouped into one of four categories (from the most serious, Category I, immediate threat to human life, to the least serious, Category IV, administrative noncompliance) and included:

$$
\begin{aligned}
& 0 \text { - Category I Findings } \\
& 10 \text { - Category II Findings } \\
& 25 \text { - Category III Findings } \\
& 23 \text { - Category IV Findings }
\end{aligned}
$$

Remedial actions have been initiated on all 58 findings, with work completed or scheduled in the Tri-Party Agreement (Ecology et al. 1996) on 51 findings and work partially completed on seven findings. Many of the findings are included in the Tri-Party Agreement and remedial actions scheduled and tracked in that document are considered here as being completed. However, none of these findings have been closed officially by DOE-HQ. The status of these findings as described in the draft Tiger Team Assessment of the Hanford Site, DOE/EH-0139, July 18, 1990 are included in this document. The Tiger Team phrase "Non Issue" was apparently an expression that the finding was not within the scope of the Assessment rather than an opinion that the finding should be closed.

The 58 findings were tracked on WHC's Quality Environmental Safety Tracking (QUEST) system database. 
HNF-MR-0535, Rev. 0

This page intentionally left blank. 


\section{DISTRIBUTION}

U.S. Department of Energy, Richland Operations Office

MSIN

S. E. Clarke

A5- 15

J. B. Hall

A5- 15

P. W. Kruger

A5-54

J. E. Rasmussen

A5 -15

D. C. Ward

A5-15

Bechtel Hanford, Inc.

R. J. Landon

$\mathrm{H} 0-18$

J. G. Woolard

$\mathrm{H} 0-17$

Fluor Daniel Hanford, Inc.

W. D. Adair

H6-21

J. A. Bates

H6-36

R. C. Brunke

H6-21

C. C. Chamberlain-Dow

B3-70

C. G. Mattsson

H5-20

S. M. Price

H6-23

W. E. Toebe

$\mathrm{H} 6-22$

L. K. Trent

H8-67

B. D. Williamson

B3-15

Pacific Northwest National Laboratory

R. W. Bryce

K6-91

R. L. Dirkes

K6-75

Hanford Technical Library

K1-11

Rust Federal Services of Hanford Inc.

W. E. Davis

H6-36

L. P. Diediker (10)

H6-36

D. W. Fritz

H6-36

B. P. Gleckler

H6-36

E. M. Greager

H6-36

J. J. Luke

$\mathrm{H} 6-36$

D. E. McKenney

H6-06

Distr-1 
Rust Federal Services of Hanford Inc (cont)

D. L. Mitchell

H6-29

K. M. Quigley

H6-06

D. L. Renberger

T3-04

D. B. VanLeuven

H6-10

R. T. Wilde

H6-10

J. A. Winterhalder

H6-21

Rust Federal Services Northwest

P. K. Brockman H1-11

J. J. Dorian $\quad$ H6-30

A. R. Johnson H6-20

B. M. Markes H6-20

S. M. McKinney $\quad$ S3-24

R. M. Mitchell $\quad$ H6-29

$\begin{array}{ll}\text { C. J. Perkins } & \text { S3-24 }\end{array}$

Lockheed Martin Services, Inc.

Central Files $\quad$ A3-88

DPC H6-08

EDMC $\cdot$ H6-08 